\title{
Phytoremediation of Soils Contaminated with Metals and Metalloids at Mining Areas: Potential of Native Flora
}

\author{
Paulo J.C. Favas, João Pratas, Mayank Varun, \\ Rohan D'Souza and Manoj S. Paul
}

Additional information is available at the end of the chapter

http://dx.doi.org/10.5772/57469

\section{Introduction}

Contaminated soils and residues can be remediated by various methods, such as: removal, isolation, incineration, solidification/stabilization, vitrification, thermal treatment, solvent extraction, chemical oxidation, etc. These methods have the disadvantage of being very expensive and in some cases, they involve the movement of contaminated materials to treatment sites thus, adding risks of secondary contamination [1-3]. Therefore, currently preference is being given to in situ methods that are less environmentally disruptive and more economical. In this context, biotechnology offers phytoremediation techniques as a suitable alternative.

Phytoremediation can be understood as the use of plants (trees, shrubs, grasses and aquatic plants) and their associated microorganisms in order to remove, degrade or isolate toxic substances from the environment [3-8]. The word "phytoremediation" derives from the Greek «phyton», meaning "plant", and Latin «remedium», which means "to remedy" or "to correct".

Substances that may be subjected to phytoremediation include metals ( $\mathrm{Pb}, \mathrm{Zn}, \mathrm{Cd}, \mathrm{Cu}, \mathrm{Ni}, \mathrm{Hg}$ ), metalloids (As, $\mathrm{Sb}$ ), inorganic compounds $\left(\mathrm{NO}^{3-} \mathrm{NH}^{4+}, \mathrm{PO}_{4}{ }^{3-}\right)$, radioactive chemical elements (U, Cs, Sr), petroleum hydrocarbons (BTEX), pesticides and herbicides (atrazine, bentazone, chlorinated and nitroaromatic compounds), explosives (TNT, DNT), chlorinated solvents (TCE, PCE) and industrial organic wastes (PCPs, PAHs), and others [5]. 


\section{Phytoremediation strategies}

Phytoremediation techniques include different modalities, depending on the chemical nature and properties of the contaminant (if it is inert, volatile or subject to degradation in the plant or in the soil) and the plant characteristics (Figure 1). Thus, phytoremediation essentially comprise six different strategies, though more than one may be used by the plant simultaneously.

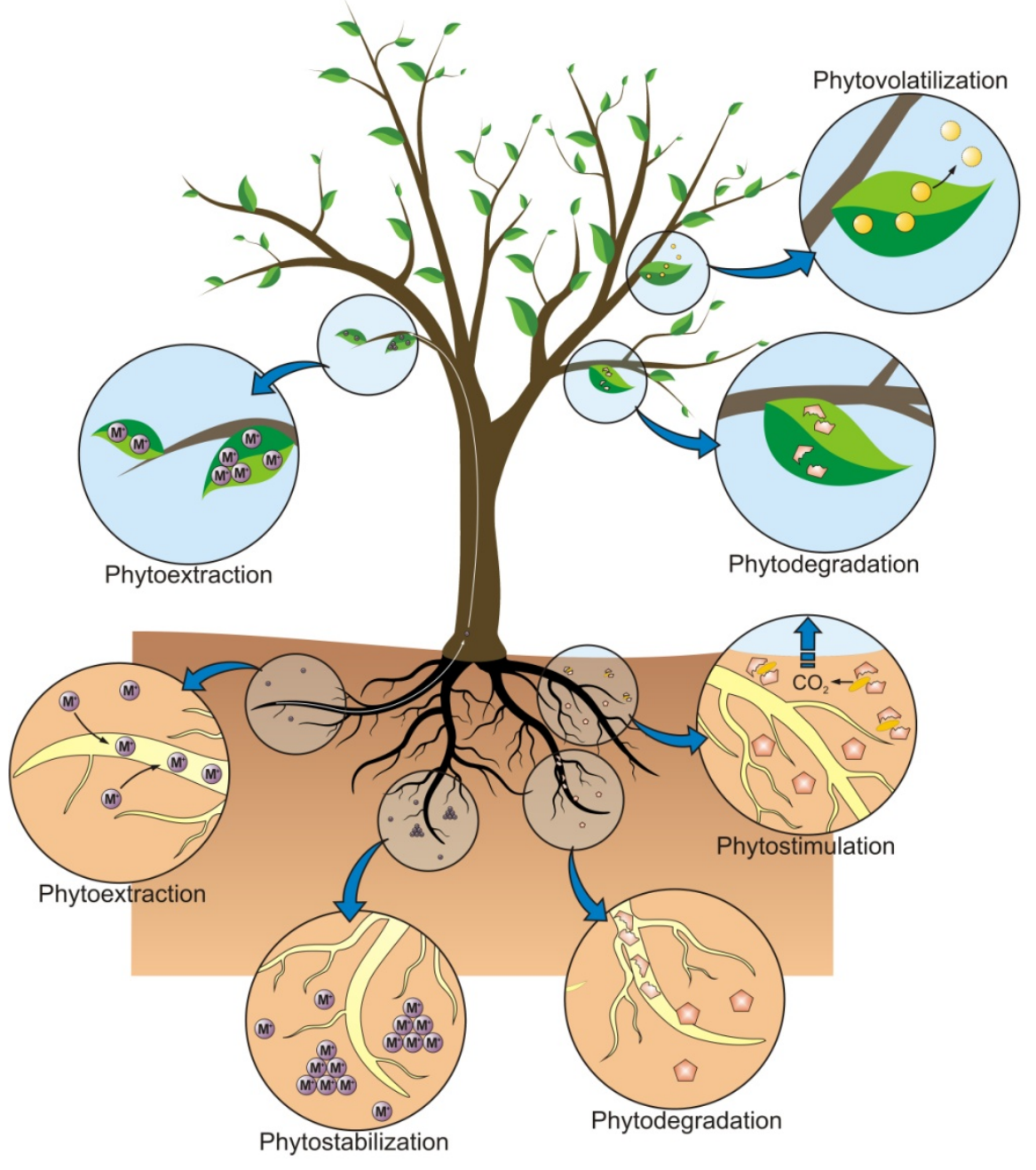

Figure 1. Schematic representation of phytoremediation strategies. 
1. Phytodegradation (Phytotransformation): organic contaminants are degraded (metabolized) or mineralized inside plant cells by specific enzymes that include nitroreductases (degradation of nitroaromatic compounds), dehalogenases (degradation of chlorinated solvents and pesticides) and laccases (degradation of anilines). Populus species and Myriophyllium spicatum are examples of plants that have these enzymatic systems $[9,10]$.

2. Phytostabilization (Phytoimmobilization): contaminants, organic or inorganic, are incorporated into the lignin of the cell wall of roots cells or into humus. Metals are precipitated as insoluble forms by direct action of root exudates and subsequently trapped in the soil matrix. The main objective is to avoid mobilization of contaminants and limit their diffusion in the soil [3,11-13]. Species of genera Haumaniastrum, Eragrostis, Ascolepis, Gladiolus and Alyssum are examples of plants cultivated for this purpose.

3. Phytovolatilization: this technique relies on the ability of some plants to absorb and volatilize certain metals/metalloids. Some element ions of the groups IIB, VA and VIA of the periodic table (specifically $\mathrm{Hg}$, Se and $\mathrm{As}$ ) are absorbed by the roots, converted into non-toxic forms, and then released into the atmosphere. As examples the species Astragalus bisulcatus and Stanleya pinnata for Se or transgenic plants (with bacterial genes) of Arabidopsis thaliana, Nicotiana tabacum, Liriodendron tulipifera or Brassica napus for $\mathrm{Hg}$ can be mentioned [13-18]. This technique can also be used for organic compounds.

4. Phytoextraction (Phytoaccumulation, Phytoabsorption or Phytosequestration): this involves the absorption of contaminants by roots followed by translocation and accumulation in the aerial parts. It is mainly applied to metals $(\mathrm{Cd}, \mathrm{Ni}, \mathrm{Cu}, \mathrm{Zn}, \mathrm{Pb})$ but can also be used for other elements (Se, As) and organic compounds. This technique preferentially uses hyperaccumulator plants, that have the ability to store high concentrations of specific metals in their aerial parts $(0.01 \%$ to $1 \%$ dry weight, depending on the metal). Elsholtzia splendens, Alyssum bertolonii, Thlaspi caerulescens and Pteris vittata are known examples of hyperaccumulator plants for $\mathrm{Cu}, \mathrm{Ni}, \mathrm{Zn} / \mathrm{Cd}$ and As, respectively [3,19-26].

5. Phytofiltration: this uses plants to absorb, concentrate and/or precipitate contaminants, particularly heavy metals or radioactive elements, from an aqueous medium through their root system or other submerged organs. The plants are kept in a hydroponic system, whereby the effluents pass and are "filtered" by the roots (Rhizofiltration), or other organs that absorb and concentrate contaminants $[13,27,28]$. Plants with high root biomass, or high absorption surface, with more accumulation capacity (aquatic hyperaccumulators) and tolerance to contaminants achieve the best results. Promising examples include Helianthus annus, Brassica juncea, Phragmites australis, Fontinalis antipyretica and several species of Salix, Populus, Lemna and Callitriche [3,16,29-31].

6. Rhizodegradation (Phytostimulation): growing roots promote the proliferation of degrading rhizosphere microorganisms which utilize exudates and metabolites of plants as a source of carbon and energy. In addition, plants may exude biodegrading enzymes themselves. The application of phytostimulation is limited to organic contaminants [3,27]. The microbial community in the rhizosphere is heterogeneous due to variable spatial 
distribution of nutrients, however species of the genus Pseudomonas are the predominant organisms associated with roots $[13,32,33]$.

There are other strategies, which are considered categories of phytoremediation by some authors, but actually, they are mixed techniques or variations of the above mentioned strategies. These include:

a. Hydraulic barriers: some large trees, particularly those with deep roots (e.g., Populus sp.), remove large quantities of groundwater during transpiration. Contaminants in this water are metabolized by plant enzymes, and vaporized together with water or simply sequestered in plant tissues [3,34].

b. Vegetation covers: Herbs (usually grasses), eventually shrubs or trees, establish on landfills or tailings, are used to minimize the infiltration of rain water, and contain the spread of pollutants. The roots increase soil aeration thus, promoting biodegradation, evaporation and transpiration [7,35-37]. The difficulty of this technique is that tailings generally are not suitable for the development of plant roots. However, various investigations have been undertaken with the aim of developing processes of cultivation in tailings. For example a technique in which an organic soil composed of sawdust, plant remains, and some NPK-fertilizers is deposited on the surface was utilized by Hungarian agronomists (Biological Reclamation Process, BRP), [38]. The workers were able to obtain, at the end of a single biological cycle, 76 different plant species including cereals, shrubs, fruit trees and even large trees like oaks and pines.

c. Constructed wetlands: these are ecosystems consisting of organic soils, microorganisms, algae and vascular aquatic plants in areas where the water level is at/near the surface, at least part of the year. All the components work together in the treatment of effluents, through the combined actions of filtration, ion exchange, adsorption and precipitation $[27,39,40]$. It is the oldest method of wastewater treatment and is not regarded as proper phytoremediation, since it is based on the contributions of the entire system [3,41]. Good cleaning efficiency, low cost of construction along with easy operation and maintenance are the main advantages. It is widely applied in the treatment of domestic, agricultural and industrial waste water, but has proved to be suitable also for treating acid mine drainages [42-45].

d. Phytodesalination: it is a recently reported [13,46] emerging technique that utilizes halophytes to remove excess salts from saline soils. The potential of Suaeda maritima and Sesuvium portulacastrum in removal and accumulation of $\mathrm{NaCl}$, from highly saline soils, has been demonstrated [47]. Although it has its peculiarities, this technique is a modality of phytoextraction.

\section{Advantages and limitations of phytoremediation}

Phytoremediation offers several advantages, but also some disadvantages, which should be considered when seeking to apply this technology (Table 1). If low cost is an advantage, the 
time necessary to observe the results can be long. The pollutant concentration and the presence of other toxins should be within the tolerance limits of the plant to be used. Selecting plants with the efficiency for remediating varied contaminants simultaneously is not easy. These limitations and the possibility of these plants entering in the food chains, should be taken into account when applying this technology.

\begin{tabular}{|c|c|}
\hline Advantages & Limitations \\
\hline In situ and passive technique & $\begin{array}{l}\text { Limited to shallow soils or where contamination is } \\
\text { localized to the surface }(<5 \mathrm{~m})\end{array}$ \\
\hline Uses solar energy and is low cost & $\begin{array}{l}\text { Still under development and therefore not accepted by } \\
\text { many regulatory agencies }\end{array}$ \\
\hline $\begin{array}{l}\text { Has reduced environmental impact and contributes to } \\
\text { the landscape improvement }\end{array}$ & $\begin{array}{l}\text { There is little knowledge of farming, genetics, } \\
\text { reproduction and diseases of phytoremediating plants }\end{array}$ \\
\hline High acceptance by the public & $\begin{array}{l}\text { Metal concentrations in the soil can be toxic and lethal to } \\
\text { plants }\end{array}$ \\
\hline Provides habitat for animal life & Generally, plants are selective in metal remediation \\
\hline Reduction in dispersal of dust and contaminants by wind & $\begin{array}{l}\text { Treatment slower than the traditional physico-chemical } \\
\text { techniques }\end{array}$ \\
\hline Reduction of surface runoff & $\begin{array}{l}\text { Contamination may spread through the food chain if } \\
\text { accumulator plants are ingested by animals }\end{array}$ \\
\hline $\begin{array}{l}\text { Reduction of leaching and mobilization of contaminants } \\
\text { in soil }\end{array}$ & $\begin{array}{l}\text { Efficient phytoremediating plants may not adapt to } \\
\text { climatic and environmental conditions at contaminated } \\
\text { sites }\end{array}$ \\
\hline $\begin{array}{l}\text { Harvesting of the plants or organs that have } \\
\text { accumulated metals is easy to accomplish with existing } \\
\text { technology }\end{array}$ & $\begin{array}{l}\text { If the plants release compounds to increase the mobility } \\
\text { of the metals, these can be leached into groundwater }\end{array}$ \\
\hline The harvested biomass can be economically valuable & $\begin{array}{l}\text { The area to be decontaminated must be large enough to } \\
\text { allow application of cultivation techniques }\end{array}$ \\
\hline $\begin{array}{l}\text { Plant process more easily controlled than those of } \\
\text { microorganisms }\end{array}$ & $\begin{array}{l}\text { Toxicity and bioavailability of degradation products } \\
\text { remain largely unknown }\end{array}$ \\
\hline
\end{tabular}

Table 1. Advantages and limitations of phytoremediation $[3,7,8,48,49]$.

\section{Phytoextraction and phytostabilization}

Phytoextraction and phytostabilization are the two techniques most useful for phytoremediation of metal and metalloid contaminated soils. Phytoextraction has been widely studied, mainly due to the potential for high efficiency and possible economic value (in metal recovery, energy production) $[3,23,24,48,50,51]$. Preferably, plants used in phytoextraction should present, among others, the following characteristics [13,23,52,53]: 
1. tolerance to high concentrations of metals;

2. accumulate high concentrations in their aerial tissues;

3. rapid growth;

4. high biomass production;

5. profuse root system;

6. easy to cultivate and harvest.

Phytoextraction can only be considered effective if the accumulated contaminant is subsequently removed through harvesting (Figure 2). If most of the captured heavy metals are translocated to shoots, traditional farming methods can be used for harvesting. It is important to harvest the plants before leaf-fall or death and decomposition to ensure that contaminants do not disperse or return to the soil [20].

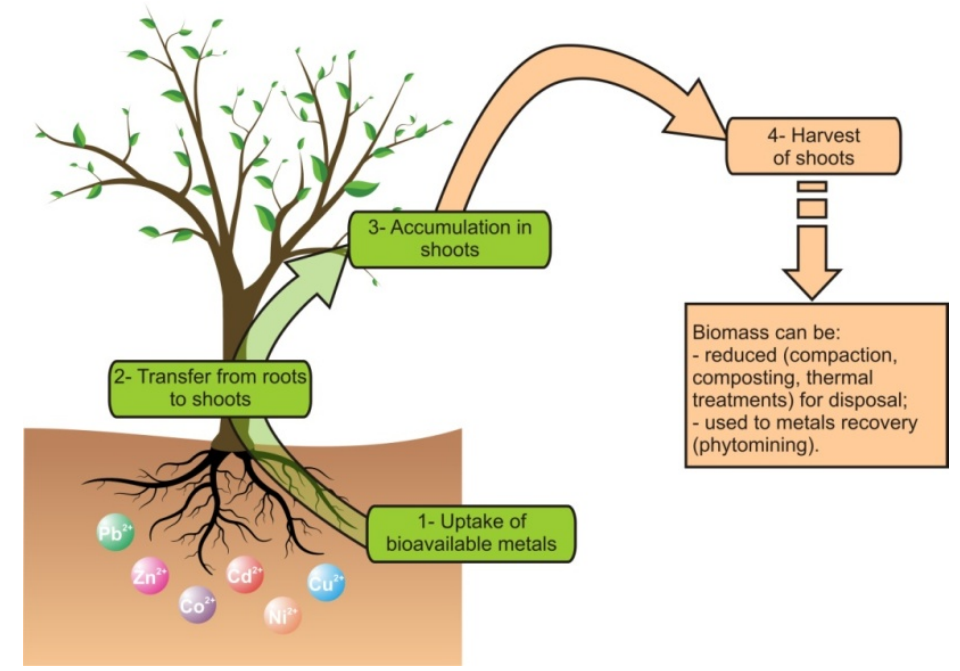

Figure 2. Schematic representation of phytoextraction of metals from soil.

After harvesting, biomass may be processed for extraction and recovery of metals (phytomining). The commercial value of metals such as $\mathrm{Ni}, \mathrm{Zn}, \mathrm{Cu}$ or $\mathrm{Co}$ may encourage the phytoremediation process. Alternatively, thermal, physical, chemical or microbiological processes can be used to reduce the volume/ weight of biomass. In the case of incineration of plants the energy produced represents an economic opportunity, and the ash can be further processed for extraction of metals. However, this process must be very careful, given the possible chemical elements accumulated, to prevent any dispersion mechanisms of contaminants.

According to McGrath and Zhao [22], phytoextraction efficiency is determined by two key factors: the ability to hyperaccumulate metals and the biomass production. Therefore, if these 
factors influence the phytoextraction, they can be optimized to improve the phytoremediation process. One possibility is the addition of chemical agents into the soil in order to increase the bioavailability of metals and their root uptake [54,55]. This form of assisted phytoremediation (or induced phytoremediation) has shown great potential and has been widely studied (Figure 3).
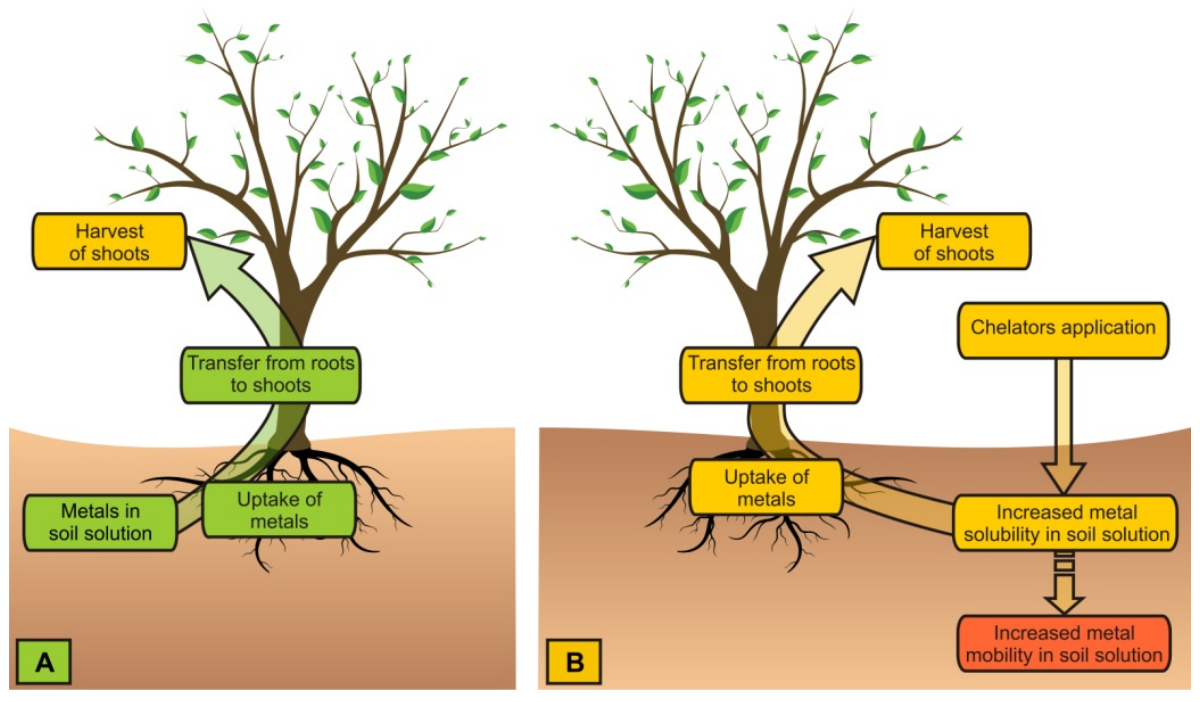

Figure 3. Schematic representation of the processes of natural (A) and assisted (B) phytoextraction.

Although hyperaccumulators are phytoextractors par excellence, usually they are low biomass producers. Thus, it is generally accepted that plants with a significant biomass production capacity can compensate their relatively lower metal accumulation capacity, to an extent where the amount of metal removed can be higher [51].

Phytoextraction potential can be estimated by calculation of bioconcentration factor (or biological absorption coefficient) and translocation factor [51,56]. The bioconcentration factor $(\mathrm{BCF})$, which is defined as the ratio of the total concentration of element in the harvested plant tissue $\left(\mathrm{C}_{\text {plant }}\right)$ to its concentration in the soil in which the plant was growing $\left(\mathrm{C}_{\text {soil }}\right)$, is calculated as follows:

$$
B C F=\frac{C_{\text {plant }}}{C_{\text {soil }}}
$$

Translocation factor (TF), defined as the ratio of the total concentration of elements in the aerial parts of the plant $\left(\mathrm{C}_{\text {shoot }}\right)$ to the concentration in the root $\left(\mathrm{C}_{\text {root }}\right)$, is calculated as follows: 


$$
T F=\frac{C_{\text {shoot }}}{C_{\text {root }}}
$$

The commercial efficiency of phytoextraction can be estimated by the rate of metal accumulation and biomass production. Multiplying the rate of accumulation (metal (g)/plant tissue $(\mathrm{kg})$ ) by the growth rate (plant tissue $(\mathrm{kg}) /$ hectare/year), gives the metal removal value $(\mathrm{g} / \mathrm{kg}$ of metal per hectare and per year) $[3,19,54,57]$. This rate of removal or extraction should reach several hundred, or at least $1 \mathrm{~kg} / \mathrm{ha} /$ year, for the species to be commercially useful, and even then, the remediation process may take from 15 to 20 years [3].

Some soils are so heavily contaminated that removal of metals using plants would take an unrealistic amount of time. The normal practice is to choose drought-resistant fast-growing crops or fodder which can grow in metal-contaminated and nutrient-deficient soils.

In contrast to phytoextraction, phytostabilization aims at reducing the mobility of contaminants in the soil. In this technique, contaminated soil is covered by vegetation tolerant to high concentrations of toxic elements, limiting the soil erosion and leaching of contaminants in to groundwater. Mobility of contaminants can be reduced by surface adsorption/accumulation in roots as well as their precipitation in rhizosphere by induced changes in $\mathrm{pH}$ or by oxidation of the root environment $[3,12,58]$. For example, the immobilization of arsenic in iron plates in the rhizosphere of salt marsh plants [58,59]. Phytostabilization can also be promoted by plant species with the capacity to exude high amounts of chelating substances. These substances lead to immobilization of contaminants by preventing their absorption, while simultaneously reducing their mobility in soil. Thus, plants with phytostabilization potential can be of great value for the revegetation of mine tailings and contaminated areas $[58,60]$.

\section{Phytoremediation potential of native flora of contaminated soils}

It is possible to find a wide variety of plant species that can colonize areas highly polluted with heavy metals and metalloids, such as mine tailings or soils degraded and contaminated by mining/industrial activities. These are referred to as metallophyte and pseudometallophyte species.

Metallophytes are endemic plant species of natural mineralized soils and, therefore, have developed physiological mechanisms of resistance and tolerance to survive on substrates with high metal levels [61,62]. Since metallophytes, in general, and hyperaccumulators, in particular, are relatively rare and usually produce reduced biomass, the study of pseudometallophytes, indigenous species of contaminated soils, is of great value. Pseudometallophyte species (or facultative metallophytes) aren't specialized in metalliferous soils and have a more extensive distribution, but, due to selective pressure, are capable to survive in metalliferous soils [63-65]. Thus, the high pressure of metalliferous soils (natural or contaminated by human action) allows the selection of populations of common species, with higher tolerance than other populations of the same species. Therefore, their capacity of adaptation to these environments and, eventually, of accumulation of metals and 
metalloids, can be very interesting with a view to their use, for example, in ecological restoration, phytoremediation and bioindication actions.

In recent decades many studies have been conducted in contaminated mining and industrial areas and in natural metalliferous soils $[35,51,58,66-78]$ in order to inventory and screen the indigenous species and evaluate their potential for phytoremediation of contaminated soils.

\subsection{Phytoremediation potencial of native flora of contaminated soils in Portugal}

Several studies to survey the indigenous plant species of diverse contaminated areas and evaluate their potential for phytoremediation have been performed in Portugal [79-93]. The authors have undertaken studies to evaluate the phytotechnological potential (phytoremediation, phytomining, bioindication, biogeochemical prospecting) of native flora of soils enriched with metals and metalloids, in distinct abandoned mining areas of tin/tungsten $(\mathrm{Sn} / \mathrm{W})$, copper $(\mathrm{Cu})$, lead $(\mathrm{Pb})$, uranium $(\mathrm{U})$, and chromium $(\mathrm{Cr})$ and the results are presented in this chapter.

\subsubsection{Native flora of old mining areas}

In the old mining areas studied, several line transects were made in mineralized and nonmineralized zones as well as tailings. Soils and plants were collected at $20 \mathrm{~m}$ intervals along the line transects $(0,20,40 \mathrm{~m}$, etc.) in circle of $\cong 2 \mathrm{~m}$ radius. At each location four random partial soil samples weighing $0.5 \mathrm{~kg}$ each were collected from 0 to $20 \mathrm{~cm}$ depth and mixed to obtain one composite sample to save time and costs. These were oven-dried at a constant temperature, manually homogenized and quartered. Two equivalent fractions were obtained from each quartered sample. One was used for the determination of $\mathrm{pH}$, and the other for chemical analysis. The samples for chemical analysis were sieved using a $2 \mathrm{~mm}$ mesh sieve to remove plant matter and subsequently screened to pass through a $250 \mu \mathrm{m}$ screen. Samples were also obtained from all species of plants whenever found growing within the $2 \mathrm{~m}$ radius of each sampling point. The plant sample focused on the aerial parts, taking into consideration similar maturity of the plants and the proportionality of the different types of tissues, or the separation of different types of tissues (leaves and stems) in some species. In the laboratory, the vegetal material was washed thoroughly, first in running water followed by distilled water, and then dried in a glasshouse. When dry, the material was milled into a homogenous powder. Soil $\mathrm{pH}$ was determined in water extract $(1: 2.5 \mathrm{v} / \mathrm{v})$. The soil and plant samples were acid-digested for elemental analysis. Analytical methods included colorimetry for $\mathrm{W}$, atomic absorption spectrophotometry (AAS, Perkin-Elmer, 2380) for Ag, Co, Cr, Cu, Fe, Mn, Ni, Pb and Zn and hydride generation system (HGS) for As and Sb. Fluorometry (Fluorat-02-2M analyzer, Lumex) was the methodology that was adopted for the determination of the $U$ content in the plant and soil samples. Data quality control was performed by inserting triplicate samples into each batch. Certified references materials were also used. 


\subsubsection{Tin/tungsten mines}

The studied areas included several abandoned Sn/W mines (Sarzedas mine, Fragas do Cavalo mine, Tarouca mine, Vale das Gatas mine, Adoria mine, Ervedosa mine, Regoufe mine, and Rio de Frades mine). Results obtained from Sarzedas (Central Portugal) and Vale das Gatas mines (Northern Portugal) are presented.

A summary of trace element data in soil from the Sarzedas mine is shown in Table 2. Among the elements present in the soils, $\mathrm{Ag}, \mathrm{As}, \mathrm{Pb}, \mathrm{Sb}$ and $\mathrm{W}$ show the most relevant anomalies. Soil $\mathrm{pH}$ was negatively correlated to mineralization. Low $\mathrm{pH}$ values observed near the mineralized area can be explained by the presence of sulfides in the mineralization [84]. High levels of sulfides, in particular pyrite and arsenopyrite that are easily weathered, favors the dissolution of toxic elements, allowing higher dispersion and bioavailability.

\begin{tabular}{lcccc}
\hline & Range & Mean & Median & Standard deviation \\
\hline $\mathrm{pH}$ & $3.3-5.2$ & 4.7 & 4.8 & 0.5 \\
\hline $\mathrm{Ag}$ & $0.69-1.91$ & 0.98 & 0.92 & 0.32 \\
\hline $\mathrm{As}$ & $11.1-651$ & 76.3 & 19.9 & 181 \\
\hline $\mathrm{Co}$ & $5.40-14.9$ & 8.80 & 8.41 & 2.60 \\
\hline $\mathrm{Cr}$ & $50.7-129$ & 96.5 & 35.1 & 26.3 \\
\hline $\mathrm{Cu}$ & $15.5-78.2$ & 40.7 & 37,356 & 12,883 \\
\hline $\mathrm{Fe}$ & $21,881-58,644$ & 39,981 & 47.0 & 22.0 \\
\hline $\mathrm{Mn}$ & $22.0-92.0$ & 50.0 & 19.7 & 10.2 \\
\hline $\mathrm{Ni}$ & $11.2-52.5$ & 21.8 & 53.9 & 106 \\
\hline $\mathrm{Pb}$ & $35.7-417$ & 85.4 & 87.8 & 1,689 \\
\hline $\mathrm{Sb}$ & $30.5-5,986$ & 663 & 53.3 & 52.3 \\
\hline $\mathrm{W}$ & $0.80-684$ & 58.8 & 24.3 \\
\hline $\mathrm{Zn}$ & $29.0-127$ & & 2.90 \\
\hline
\end{tabular}

Table 2. Trace elements content ( $\mathrm{mg} / \mathrm{kg})$ and $\mathrm{pH}$ of soil samples $(\mathrm{N}=24$, Sarzedas mine).

In the flora of Sarzedas mine area, As was accumulated in aerial tissues of Pinus pinaster and Digitalis purpurea. Therefore, these species are suited for recognizing the anomaly. High accumulation of As was present in leaves (Figure 4), and it increased in the older tissues. This translocation is a common mechanism in plants to avoid toxicity in young leaves as their metabolic activity is higher [84]. Digitalis purpurea also accumulated substantial amount of Sb (Figure 5), indicating its tolerance to this element, although the assimilation occured at low 
concentrations in the soil. Species that are capable of accumulating W are D. purpurea, Cistus ladanifer, P. pinaster, Calluna vulgaris and Helichrysum stoechas (Figure 6).

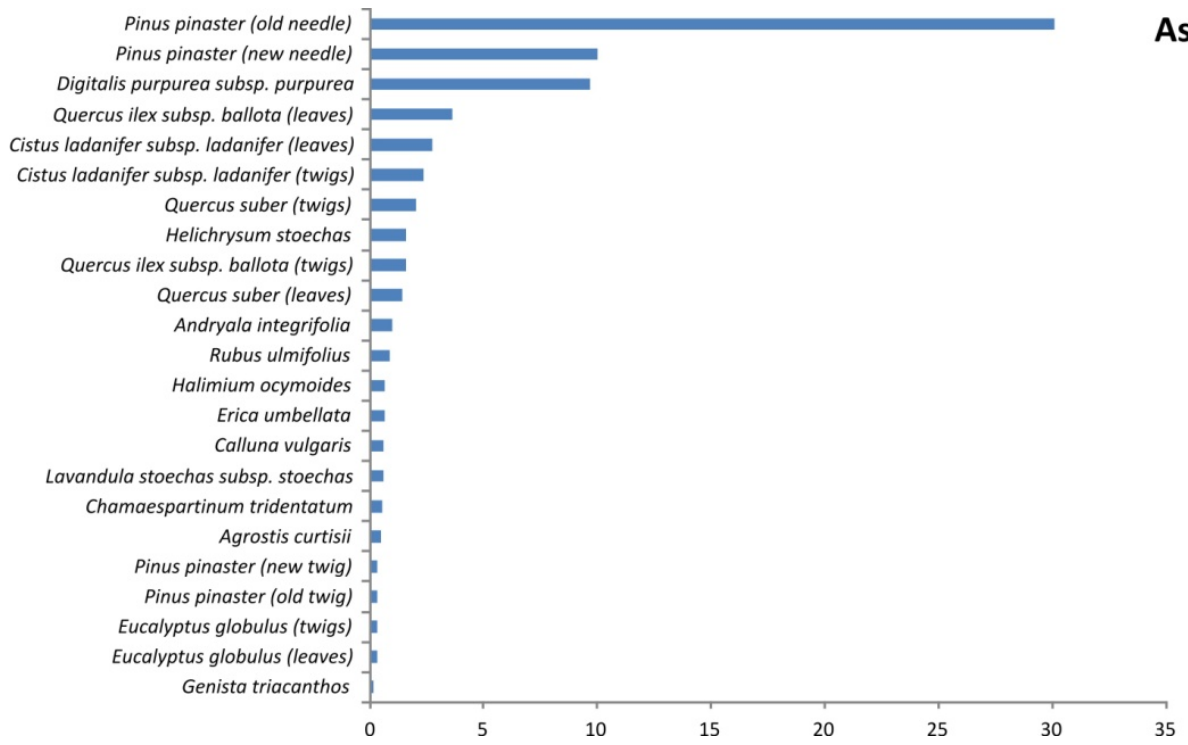

Figure 4. Accumulation of As (mg/kg DW) in plant species of the Sarzedas mining area.

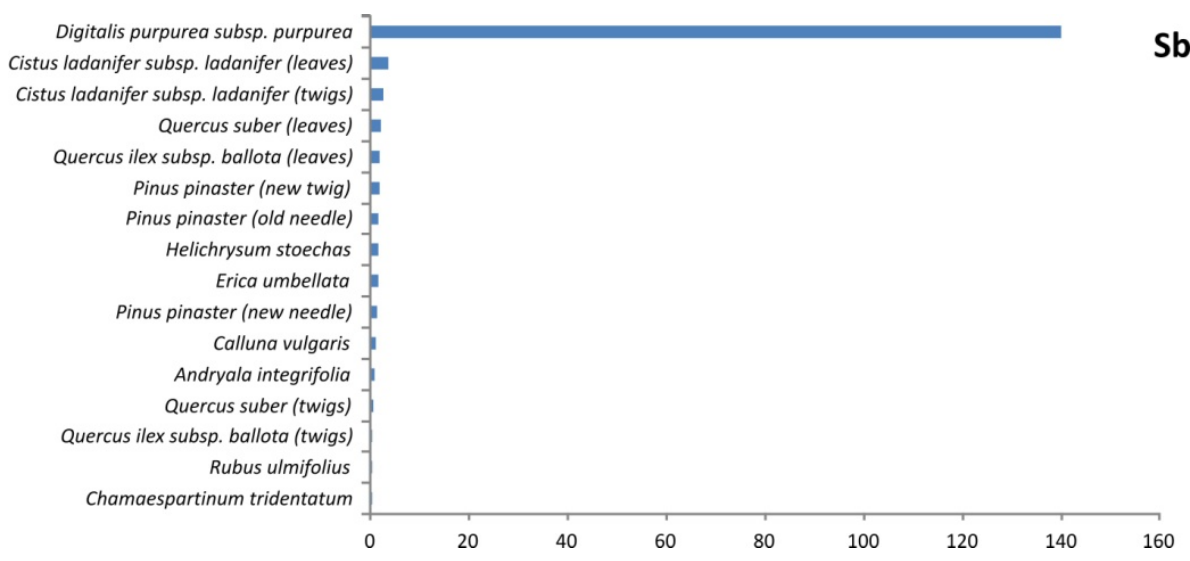

Figure 5. Accumulation of Sb $(\mathrm{mg} / \mathrm{kg} \mathrm{DW})$ in plant species of the Sarzedas mining area. 


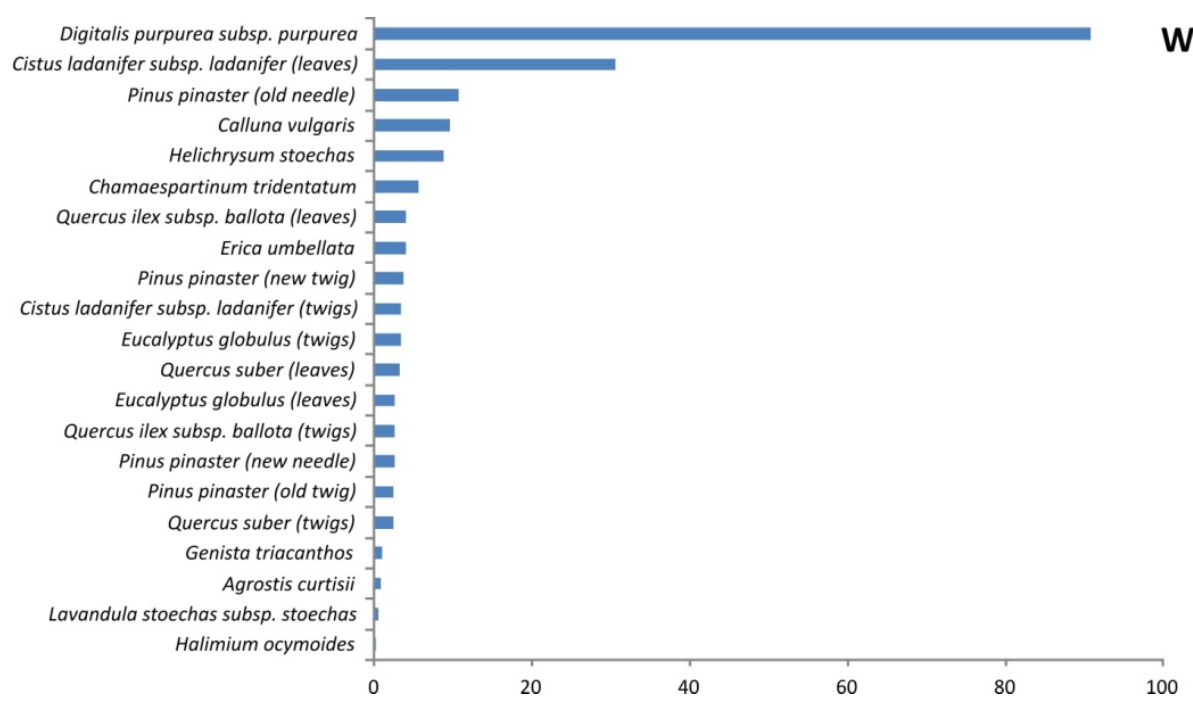

Figure 6. Accumulation of W (mg/kg DW) in plant species of the Sarzedas mining area.

It was concluded that the species and organs best suited for biogeochemical prospecting and/ or with potential for mine restoration in the Sarzedas mine area are by order of importance: 1 ) As: old needles of $P$. pinaster, aerial tissues of $C$. vulgaris, Chamaespartium tridentatum, leaves of C. ladanifer, Erica umbellata and Quercus ilex subsp. ballota; 2) Sb: D. purpurea, E. umbellata, stems of C. ladanifer, C. vulgaris, C. tridentatum and stems of P. pinaster; 3) W: D. purpurea, C. tridentatum, old stems and needles of P. pinaster, stem and leaves of C. ladanifer, E. umbellata and stems and leaves of $Q$. ilex [84].

\begin{tabular}{lcccc}
\hline & Range & Mean & Median & Standard deviation \\
\hline $\mathrm{pH}$ & $3.5-6.3$ & 5.0 & 5.0 & 0.8 \\
\hline $\mathrm{As}$ & $26.7-5,770$ & 446 & 56.7 & 1,178 \\
\hline $\mathrm{Cu}$ & $11.7-352$ & 88.0 & 29.0 & 101 \\
\hline $\mathrm{Fe}$ & $18,482-60,100$ & 33,039 & 29,443 & 12,463 \\
\hline $\mathrm{Mn}$ & $103-898$ & 336 & 167 & 248 \\
\hline $\mathrm{Ni}$ & $11.6-61.2$ & 30.6 & 23.6 & 15.1 \\
\hline $\mathrm{Pb}$ & $55.4-6,299$ & 499 & 102 & 1,285 \\
\hline $\mathrm{Zn}$ & $63.1-469$ & 180 & 125 & 112 \\
\hline $\mathrm{W}$ & $2.00-636$ & 73.8 & 10.6 & 162 \\
\hline
\end{tabular}

Table 3. Trace elements content ( $\mathrm{mg} / \mathrm{kg}$ ) and $\mathrm{pH}$ of soil samples ( $\mathrm{N}=69, \mathrm{~V}$. Gatas mine). 
Very high maximum values for $\mathrm{Pb}(6,299 \mathrm{mg} / \mathrm{kg})$, As (5,770 mg/kg) and $\mathrm{W}(636 \mathrm{mg} / \mathrm{kg})$ were observed at the Vale das Gatas mine (Table 3). The $\mathrm{Cu}-\mathrm{Mn}-\mathrm{W}-\mathrm{As}-\mathrm{Pb}-\mathrm{Zn}$ association, which reflects the presence of mineralised veins in the area, is inversely correlated with $\mathrm{pH}$ [93]. In general, the content variations in plant materials were strongly related to the content variations in soils. It has also been verified that in contaminated locations or tailings, the concentration of metals in plant tissues is high due to the high metal concentrations in the soil.

The leaves of Agrostis castellana and Holcus lanatus reflect the $\mathrm{Cu}, \mathrm{Pb}$ and $\mathrm{Ni}$ pedogeochemical anomalies. The aerial parts of Pteridium aquilinum and Juncus effusus seem to be indicative of Zn anomalies in the soil [94]. Holcus lanatus and A. castellana were the main accumulators of As (Figure 7), $\mathrm{Cu}$ (Figure 8), Fe (Figure 9) and Pb (Figure 10) and good accumulators of $\mathrm{Zn}$ (Figure 11). Pteridium aquilinum was a good accumulator of $\mathrm{As}, \mathrm{Pb}$ and $\mathrm{Zn}$ (Figures 7, 10, 11). Juncus effusus appeared to be a Zn accumulator (Figure 11).

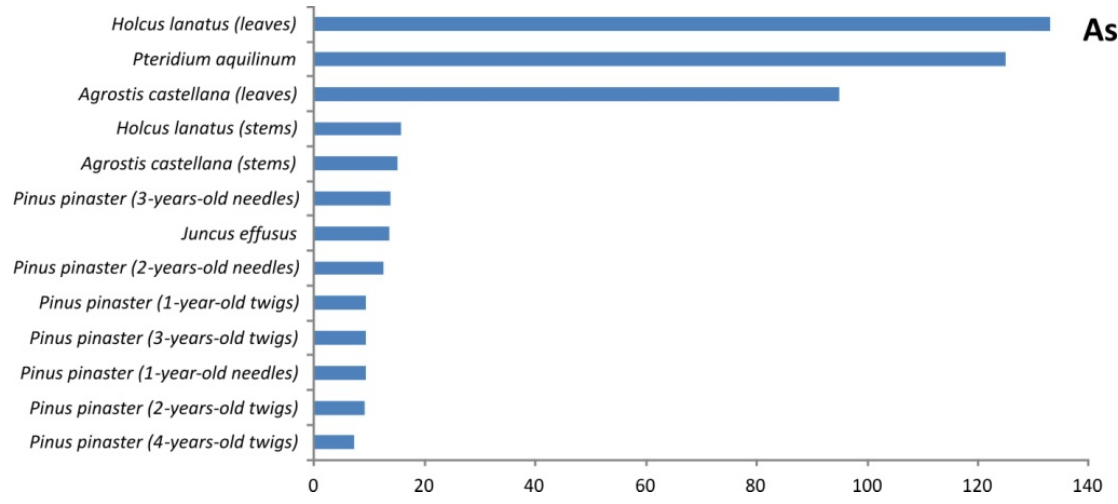

Figure 7. Accumulation of As (mg/kg DW) in plant species of the V. Gatas mining area.

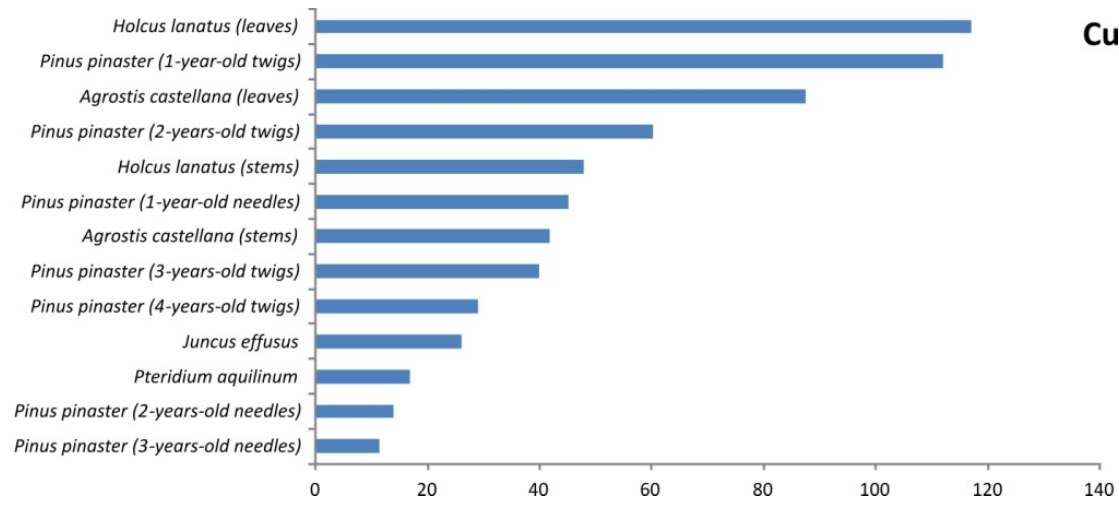

Figure 8. Accumulation of $\mathrm{Cu}(\mathrm{mg} / \mathrm{kg} \mathrm{DW})$ in plant species of the $\mathrm{V}$. Gatas mining area. 


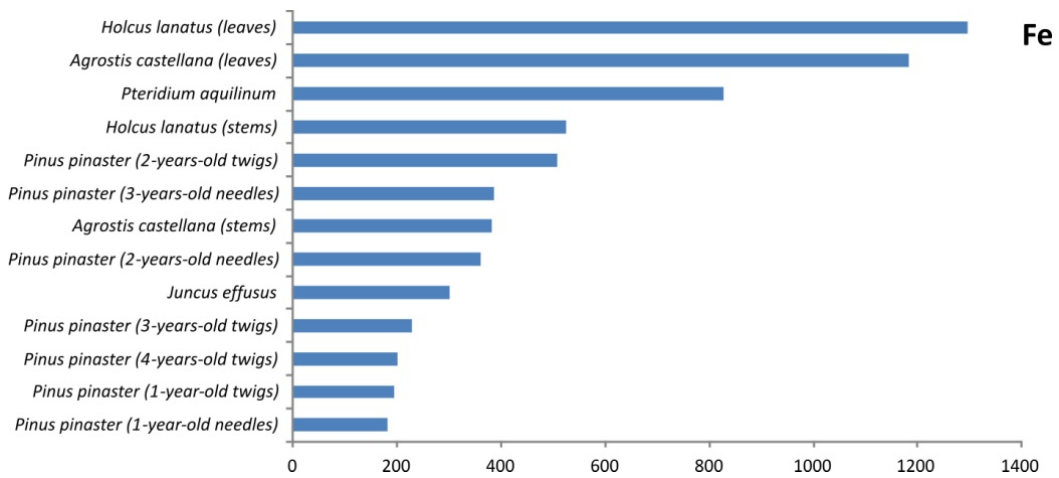

Figure 9. Accumulation of Fe (mg/kg DW) in plant species of the $\mathrm{V}$. Gatas mining area.

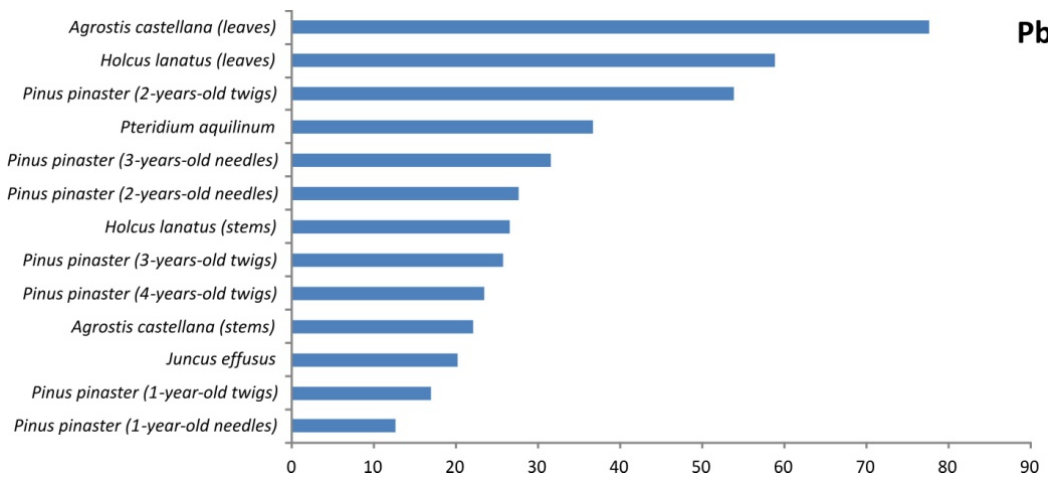

Figure 10. Accumulation of $\mathrm{Pb}(\mathrm{mg} / \mathrm{kg} \mathrm{DW})$ in plant species of the $\mathrm{V}$. Gatas mining area.

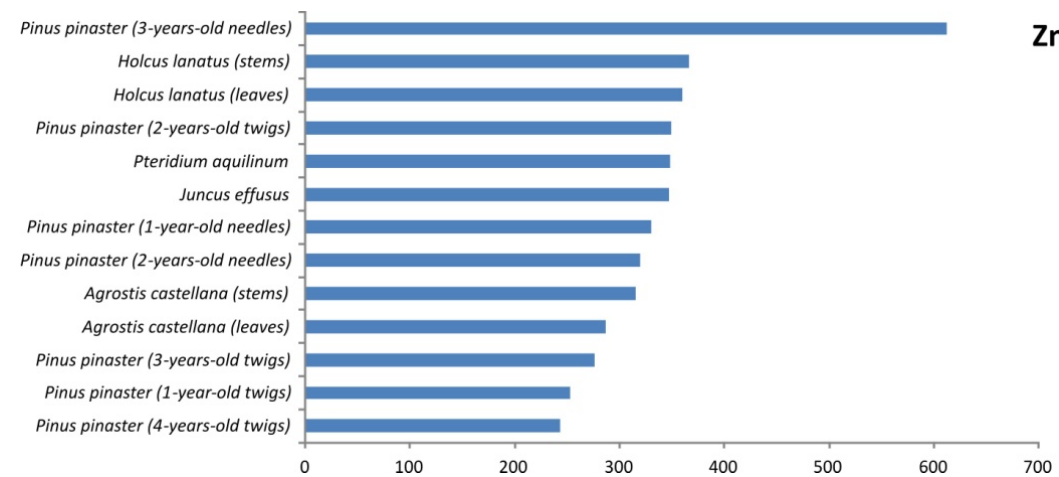

Figure 11. Accumulation of $\mathrm{Zn}(\mathrm{mg} / \mathrm{kg} \mathrm{DW})$ in plant species of the $\mathrm{V}$. Gatas mining area. 
The $P$. pinaster trees growing on the tailings and contaminated soils of Vale das Gatas mine accumulated the studied elements in quantities greater than observed in plants of the areas representative of the local geochemical background. These values were also higher than those typically observed in this species.

In the P. pinaster samples from tailings and contaminated soil locations, the older needles (2and 3-years-old) show a tendency to accumulate higher concentrations of $\mathrm{As}, \mathrm{Fe}, \mathrm{Zn}, \mathrm{Pb}$ and $\mathrm{W}$ while $\mathrm{Ni}$ and $\mathrm{Cu}$ were preferentially accumulated in young needles and stems (1-year-old) [93]. This allowed the authors to conclude that the metal/metalloid concentrations of elements in plants depend as much on the plant organ as on its age and in biogeochemical studies, it is important not to mix foliar and woody material in the same sample. The species showed a great variability in the accumulation behaviour of $\mathrm{As}, \mathrm{Fe}, \mathrm{Mn}, \mathrm{Cu}, \mathrm{Zn}, \mathrm{Pb}, \mathrm{Ni}$, and $\mathrm{W}$ with the age of the organ. Thus, the 1-year-old needles and stems accumulated higher levels of $\mathrm{Cu}$ (Figure 8) and $\mathrm{Ni}$ (Figure 12). While the older needles accumulated higher levels of $\mathrm{As}, \mathrm{Fe}, \mathrm{Pb}$, Zn and $W$ (Figures 7, 9, 10, 11 and 13). The 2-years-old stems may also be appropriate samples to detect higher levels of $\mathrm{Fe}, \mathrm{Zn}$ and $\mathrm{Pb}$.

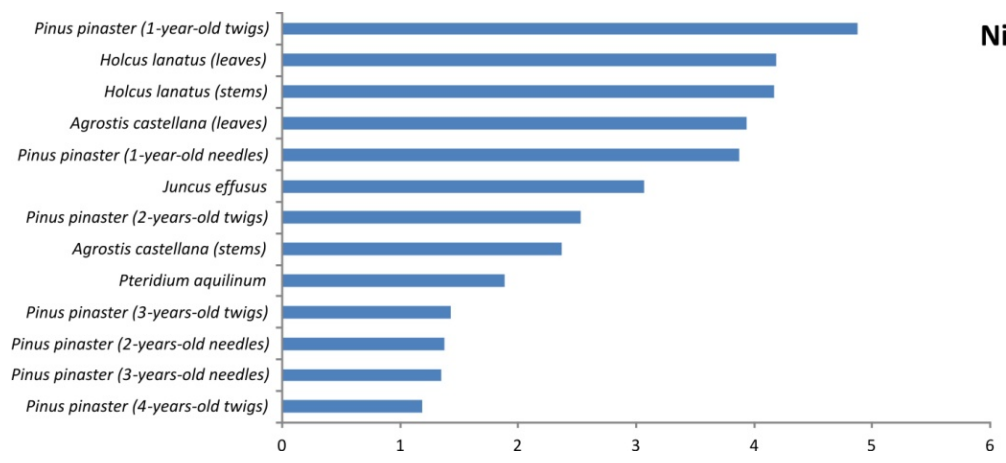

Figure 12. Accumulation of $\mathrm{Ni}(\mathrm{mg} / \mathrm{kg} \mathrm{DW})$ in plant species of the $\mathrm{V}$. Gatas mining area.

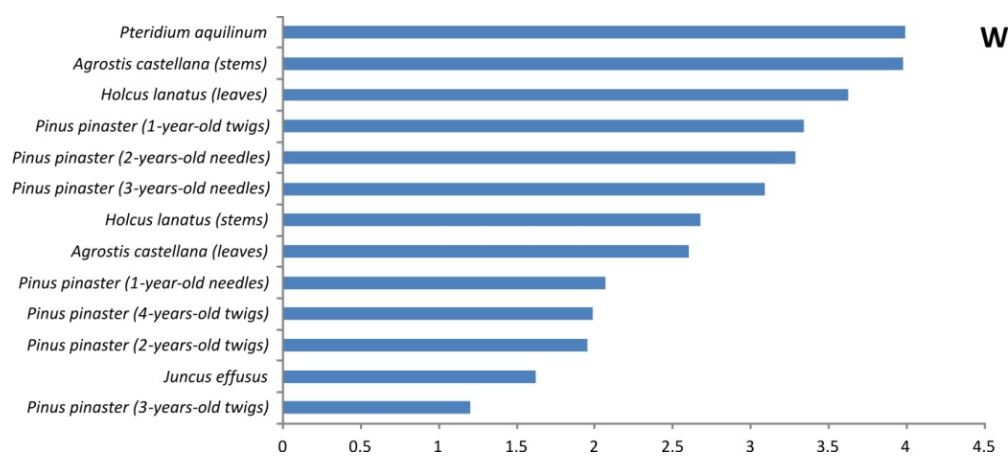

Figure 13. Accumulation of $W(\mathrm{mg} / \mathrm{kg} \mathrm{DW})$ in plant species of the $\mathrm{V}$. Gatas mining area. 


\subsubsection{Copper mines}

The São Domingos mine (abandoned in 1966) located in south-east Portugal is also included in this study. This is one of the historical mining centres, known for its activity since pre-Roman times, with extraction of gold, silver and copper [95] though copper production was the highlight.

A summary of soil trace element data is presented in Table 4. High levels of $\mathrm{As}, \mathrm{Cu}, \mathrm{Pb}$ and $\mathrm{Zn}$ were recorded in the soils. Copper concentration in soils reached up to $1,829 \mathrm{mg} / \mathrm{kg}$ as a result of the former activities at the site (copper smelter). Maximum concentration of As in soils was very high, reaching 1,291 mg/kg. The concentration of $\mathrm{Pb}$ in the soil was also very high, $2,694 \mathrm{mg} / \mathrm{kg}$ as the average value registered. The average $\mathrm{Zn}$ concentration in soils was of $218 \mathrm{mg} / \mathrm{kg}$ but it could reach $714 \mathrm{mg} / \mathrm{kg}$, a level that can be extremely toxic for plants. Cobalt and $\mathrm{Cr}$ concentrations in soils were normally low, ranging from 20.1 to $54.3 \mathrm{mg} / \mathrm{kg}$ for Co and 5.1 to $84.6 \mathrm{mg} / \mathrm{kg}$ for Cr. Nickel and Ag were also low, varying from $27.2-52.9 \mathrm{mg} / \mathrm{kg}$ and 2.5$16.6 \mathrm{mg} / \mathrm{kg}$, respectively.

\begin{tabular}{lcccc}
\hline & Range & Mean & Median & Standard deviation \\
\hline $\mathrm{pH}$ & $4.0-6.7$ & 5.1 & 5.1 & 0.6 \\
\hline $\mathrm{Ag}$ & $2.50-16.6$ & 7.50 & 7.00 & 3.60 \\
\hline $\mathrm{As}$ & $37.2-1291$ & 393 & 353 & 324 \\
\hline $\mathrm{Co}$ & $20.1-54.3$ & 31.0 & 29.4 & 8.40 \\
\hline $\mathrm{Cr}$ & $5.10-84.6$ & 26.5 & 8.30 & 31.7 \\
\hline $\mathrm{Cu}$ & $87.3-1,829$ & 553 & 444 & 443 \\
\hline $\mathrm{Ni}$ & $27.2-52.9$ & 42.2 & 43.9 & 6.60 \\
\hline $\mathrm{Pb}$ & $234-12,218$ & 2,694 & 2,355 & 2,345 \\
\hline $\mathrm{Zn}$ & $104-714$ & 218 & 163 & 145 \\
\hline
\end{tabular}

Table 4. Trace elements content $(\mathrm{mg} / \mathrm{kg})$ and $\mathrm{pH}$ of soil samples $(\mathrm{N}=21, \mathrm{~S}$. Domingos mine).

In plants, $\mathrm{Pb}$ concentration was rather high for some species, varying from 2.9 to $84.9 \mathrm{mg} / \mathrm{kg}$ dry weight (DW) (Figure 14). Semi-aquatic species sampled in the mining area, Juncus conglomeratus and Scirpus holoschoenus, showed high accumulation of $\mathrm{Pb}$ in plant tissues. Lead above $20 \mathrm{mg} / \mathrm{kg}$ DW was found in leaves of two species of Cistus, typical Mediterranean shrubs known for their tolerance to drought and low nutrients availability. Arsenic concentration in plant tissues ranged from 0.3 to $23.5 \mathrm{mg} / \mathrm{kg}$ DW. Maximum As was recorded in J. conglomeratus, Thymus mastichina, J. effusus and S. holoschoenus [82]. Semi-aquatic species from the Juncaceae family showed the highest content of both metals. Copper concentration in plant tissues ranged from 3.60 to $28.9 \mathrm{mg} / \mathrm{kg}$ DW (Figure 15). These $\mathrm{Cu}$ values are within the range considered normal for plants [96]. The species Cistus monspeliensis and Daphne gnidium showed the highest Zn concentrations [82]. A few trees, Eucalyptus, Quercus and Pinus species, were found in the contaminated area showing accumulation of different metals in the aboveground tissues. Due to their high biomass, they can be very effective for metals phytoextraction and 
phytostabilization especially when established in the less contaminated soils on the peripheral zone of the study area [82].

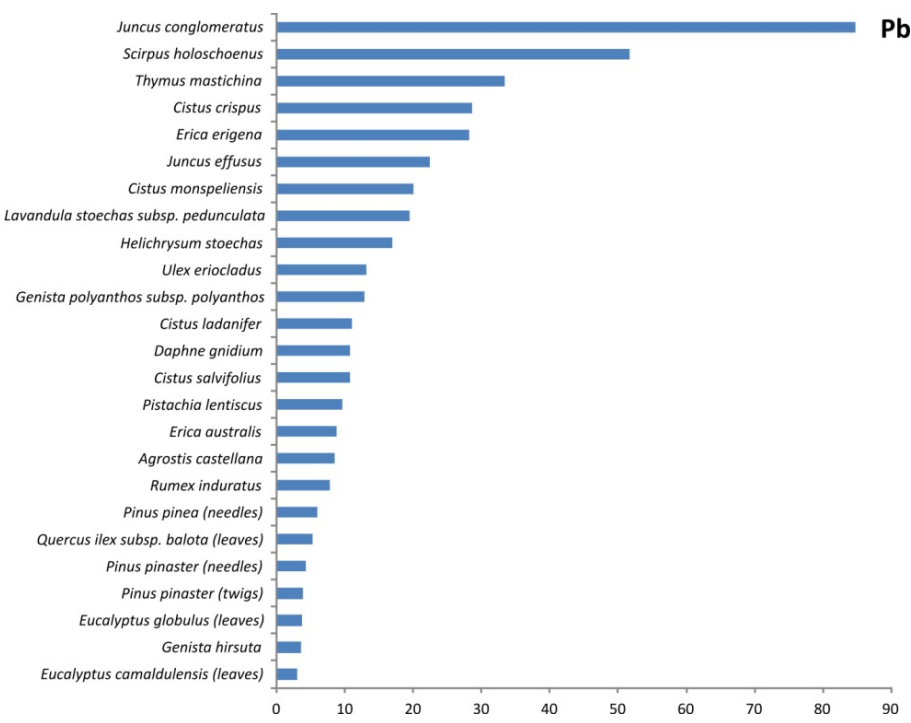

Figure 14. Accumulation of $\mathrm{Pb}(\mathrm{mg} / \mathrm{kg} \mathrm{DW})$ in plant species of the $\mathrm{S}$. Domingos mining area.

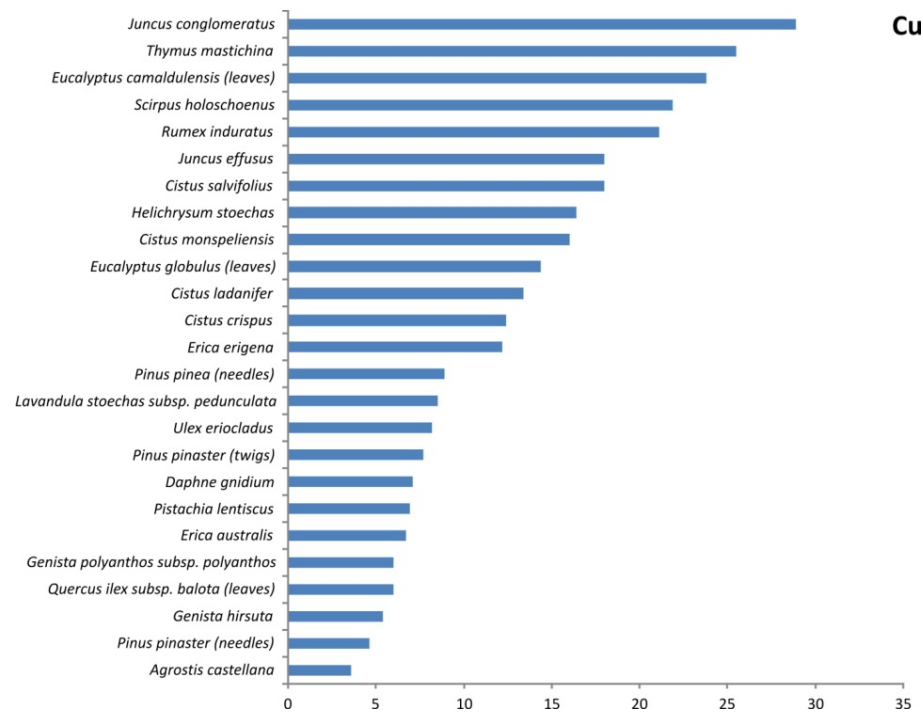

Figure 15. Accumulation of $\mathrm{Cu}(\mathrm{mg} / \mathrm{kg} \mathrm{DW})$ in plant species of the S. Domingos mining area. 


\subsubsection{Lead mines}

The Barbadalhos mine is an abandoned $\mathrm{Pb}$ mine in Central Portugal. It was exploited for $\mathrm{Pb}$ by underground mining from 1887 till the 1940s. The concentrated ore was smelted on site. As per the usual practice at the time, tailings were deposited on the ground.

Metal concentrations in soil are shown in Table 5. Lead concentration in soils reached 9,331 $\mathrm{mg} / \mathrm{kg}$ while the average value was $928 \mathrm{mg} / \mathrm{kg}$; obviously due to mining of galena at the site. In soils from mineralized zone, the mean $\mathrm{Pb}$ concentration $(2,380 \mathrm{mg} / \mathrm{kg})$ was nearly 9 times the threshold for industrial soils suggested by Canadian Environmental Quality Guidelines [97].

\begin{tabular}{lcccc}
\hline & Range & Mean & Median & Standard deviation \\
\hline $\mathrm{pH}$ & $3,6-6.4$ & 4.7 & 4.6 & 0.5 \\
\hline $\mathrm{Ag}$ & $0.71-13.0$ & 1.71 & 1.06 & 2.03 \\
\hline $\mathrm{As}$ & $2.77-208$ & 16.9 & 8.07 & 31.7 \\
\hline $\mathrm{Co}$ & $3.74-50.5$ & 20.1 & 16.7 & 12.4 \\
\hline $\mathrm{Cr}$ & $61.3-196$ & 89.0 & 85.7 & 22.1 \\
\hline $\mathrm{Cu}$ & $21.4-193$ & 41.7 & 34.5 & 27.9 \\
\hline $\mathrm{Fe}$ & $24,145-98,510$ & 40,283 & 38,497 & 13,751 \\
\hline $\mathrm{Mn}$ & $44.4-2,224$ & 596 & 381 & 588 \\
\hline $\mathrm{Ni}$ & $7.68-87.0$ & 30.5 & 28.1 & 12.2 \\
\hline $\mathrm{Pb}$ & $24.4-9,331$ & 928 & 68.8 & 2,119 \\
\hline $\mathrm{Zn}$ & $30.4-517$ & 134 & 90.3 & 109 \\
\hline
\end{tabular}

Table 5. Trace elements content $(\mathrm{mg} / \mathrm{kg})$ and $\mathrm{pH}$ of soil samples ( $\mathrm{N}=45$, Barbadalhos mine).

Samples from 49 species of the native flora were investigated at this site. Individual elements and species displayed different trends of accumulation. All plants collected along mineralized zone accumulated eight metals ( $\mathrm{Ag}, \mathrm{Co}, \mathrm{Cr}, \mathrm{Cu}, \mathrm{Fe}, \mathrm{Ni}, \mathrm{Pb}$, and $\mathrm{Zn}$ ) but many plants from nonmineralized zone accumulated only five metals ( $\mathrm{Ag}, \mathrm{Cu}, \mathrm{Fe}, \mathrm{Pb}$, and $\mathrm{Zn}$ ). A few however did accumulate the remaining three $(\mathrm{Co}, \mathrm{Cr}$, and $\mathrm{Ni})$; bringing the count of metals accumulated at par with those of mineralized zone [92].

Most plants were seen to be tolerant of soil $\mathrm{Pb}$ concentrations. In mineralized zone, $\mathrm{Pb}$ concentrations in plants ranged from 1.11 to $548 \mathrm{mg} / \mathrm{kg}$ DW. This is far above the $100-400 \mathrm{mg}$ $\mathrm{Pb} / \mathrm{kg}$ content considered toxic for most plants [98]. Significant accumulation of $\mathrm{Pb}$ was seen in Cistus salvifolius (548 mg/kg), Lonicera periclymenum (318 mg/kg), Anarrhinum bellidifolium, Phytolacca americana, Digitalis purpurea, Mentha suaveolens $(255-217 \mathrm{mg} / \mathrm{kg})$ [listed in decreasing order] (Figure 16). Pteridophytes like Polystichum setiferum, Pteridium aquilinum, and 
Asplenium onopteris also showed 117 - $251 \mathrm{mg} / \mathrm{kg} \mathrm{Pb}$ in aerial parts. In plants from nonmineralized zone, $\mathrm{Pb}$ content was not significant ranging from 0.94 to $11.6 \mathrm{mg} / \mathrm{kg}$.

Though at first glance maximum $\mathrm{Pb}$ content observed in trees like Acacia dealbata $(84 \mathrm{mg} / \mathrm{kg}$ : leaves), Olea europaea (62 mg/kg: twigs), and Quercus suber (58 mg/kg: twigs) from mineralized zone is not very impressive compared to that of smaller plants mentioned above, nevertheless these trees can be very effective due to their higher biomass. When combined with the hardy nature, biomass and abundance of this species, the moderate accumulation indicates immense potential for phytoextraction of $\mathrm{Pb}$ in the area [92].

In mineralized zone, $\mathrm{Zn}$ concentrations in plants reached $1,020 \mathrm{mg} / \mathrm{kg}$ in D. purpurea. And ranged from 262 to $887 \mathrm{mg} / \mathrm{kg}$ in L. periclymenum, P. americana, Solanum nigrum, P. setiferum, M. suaveolens, Viola riviniana, and A. bellidifolium [listed in decreasing order] [92].

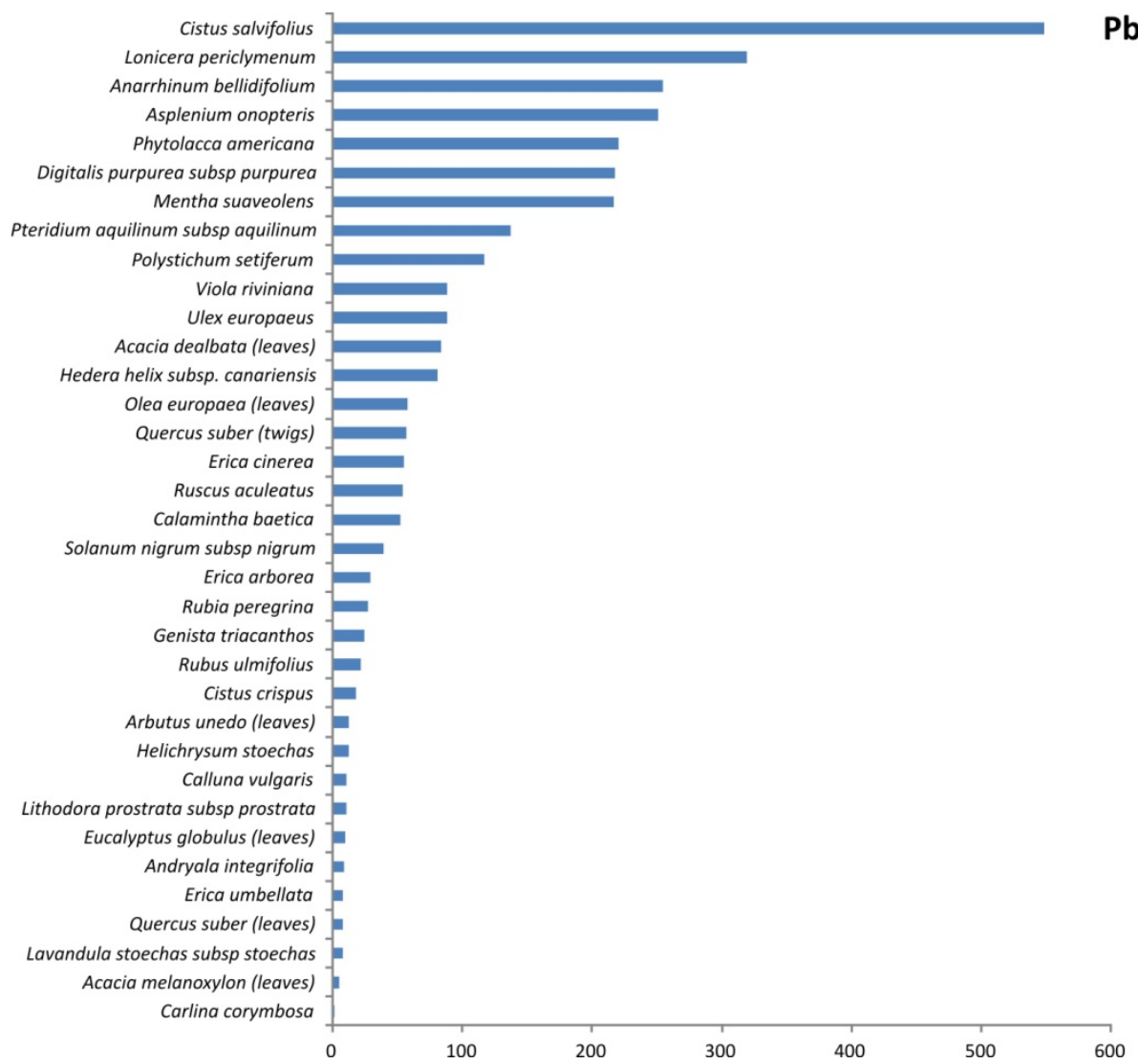

Figure 16. Accumulation of $\mathrm{Pb}(\mathrm{mg} / \mathrm{kg} \mathrm{DW})$ in plant species of the Barbadalhos mining area. 


\subsubsection{Uranium mines}

The old U mine of Sevilha (Central Portugal) is one of several small mines exploited by ENU (Portuguese Uranium Company). After the removal of the main ore body, the site was filled with the mine wastes and a reclamation process was initiated. This action was somewhat unsuccessful because the selected allochthonous plant species (Lupinus sp.) did not survive.

Current U soil contamination on the Sevilha mine ranges from 8 to $560 \mathrm{mg} / \mathrm{kg}$ [99]. Species of Compositae and Ericaceae (among the most abundant families of terrestrial plants) accumulated highest $U$ concentrations (Figure 17). Among Compositae members, an average of 4.91 $\mathrm{mg} / \mathrm{kg} \mathrm{DW}$ and a maximum of $13.1 \mathrm{mg} / \mathrm{kg} \mathrm{DW}$ was found in Helichrysum stoechas and an average of $4.07 \mathrm{mg} / \mathrm{kg}$ DW and a maximum of $10.5 \mathrm{mg} / \mathrm{kg}$ DW was recorded in Hypochaeris radicata (Figure 17). In Erica umbellata an average of $1.70 \mathrm{mg} / \mathrm{kg}$ DW and a maximum of 7.50 $\mathrm{mg} / \mathrm{kg}$ DW were obtained (Figure 17). Even though the concentrations obtained in the latter are not high, it is particularly interesting because it has a high bio-productivity. This accumulation potential might be intensified if uptake enhancement strategies, such as addition of citric acid, are adopted. A restoration program can be applied to the soils of Sevilha mine by adopting revegetation with endemic species allied to a process of continuous phytoremediation that avoids dispersion of $U$ into the streamlets.

Even though the soils in this mine are not highly contaminated, the lixiviation of refilling materials has been responsible for the dispersion of $U$ into ground and superficial water bodies. These waters are being used for subsistence agriculture and, therefore, the risk of contamination spreading to humans can be acute, due to food chain accumulation [99]. The plant survey revealed that some of the native plant species are well adapted to $U$ contamination in soils, therefore, they are metallotolerants. Their phytoremediation potential has to be evaluated. Dispersion of $U$ into the streamlets can be minimized by a strategic combination of terrestrial and aquatic plant phyto-systems. Revegetation with Helichrysum stoechas, Hypochaeris radicata and Erica umbellata will allow fixation of $U$ in the plants and a consequent reduction in its dispersion. This site can be an excellent prototype for the restoration of other mines in Portugal where levels of contamination are a matter of concern.

\subsubsection{Chromium mines (Serpentine soils)}

The abandoned mining area of Pingarela in North-east Portugal has serpentine soils and associated flora. These soils are disproportionately rich in trace elements like Ni, Cr, Co and poor in Ca. Serpentine outcrops have been referred to as barrens because they are often sparsely vegetated and extremely poor in essential nutrients, hence not of much agricultural value. Serpentine ecosystems can generally be distinguished by their grey-green or reddish rocky soils (soils are very thin), and shrubby or stunted vegetation with plants having small leathery leaves.

Plant species found on serpentine soils can be divided into two groups: (a) serpentine-tolerant or serpentine-facultative plants, which are able to survive on serpentine but grow better elsewhere; (b) serpentinicolous, serpentine-endemic or serpentine-obligate plants, which grow exclusively on serpentine soils and are not found on other substrates [83,100]. Both these 


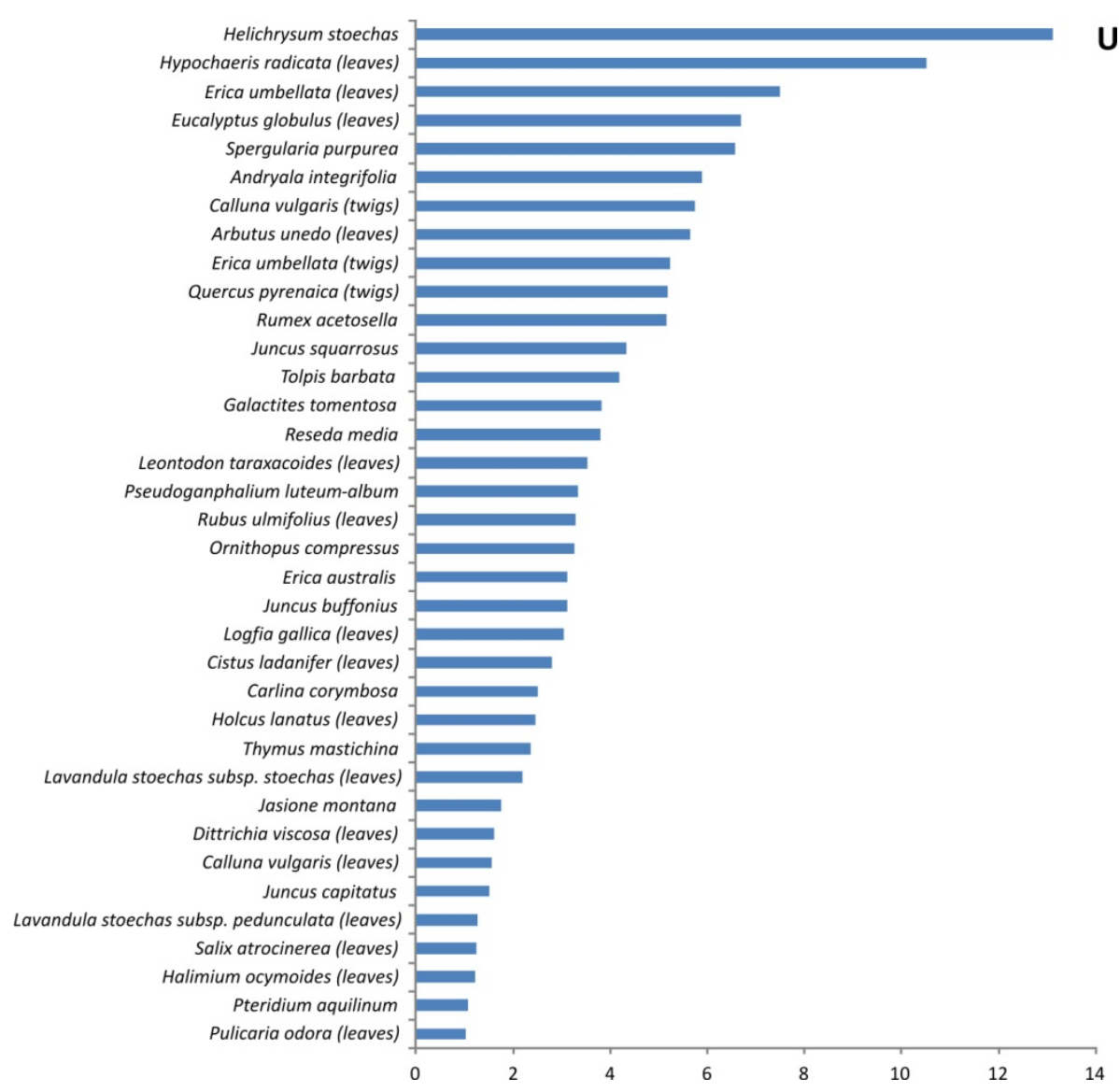

Figure 17. Accumulation of $U(\mathrm{mg} / \mathrm{kg} \mathrm{DW})$ in plant species of the Sevilha mining area.

groups include species with different efficiencies to uptake or exclude a variety of metals. Serpentinophytes often experience drought, nutrient stress and excessive exposure to heavy metal and high light intensity. This means there is less substrate in which nutrients and water can be held and made available to plants.

An area of $\sim 8,000$ ha in north-east Portugal is serpentinized with characteristic geology and flora. The serpentine plant community and respective soils were analyzed [83] to examine the trace metal budget in different tissues of the plants exhibiting resistance to trace metals. 135 plant species belonging to 39 families and respective soils were analyzed for total $\mathrm{Co}, \mathrm{Cr}, \mathrm{Cu}$, $\mathrm{Fe}, \mathrm{Mn}, \mathrm{Ni}, \mathrm{Pb}$ and $\mathrm{Zn}$. Heavy metal concentrations recorded in sampled soils are shown in Table 6. The high contents of $\mathrm{Ni}$ and $\mathrm{Cr}$ obtained were to be expected, considering the geochemistry of the sampling site. However, the high variability of $\mathrm{Cr}, \mathrm{Ni}, \mathrm{Fe}$ and $\mathrm{Mn}$ in the soils is noteworthy. 


\begin{tabular}{lcccc}
\hline & Range & Mean & Median & Standard deviation \\
\hline $\mathrm{pH}$ & $4.9-9.3$ & 6.7 & 6.7 & 0.6 \\
\hline $\mathrm{Co}$ & $56.0-151$ & 82.3 & 81.1 & 18.5 \\
\hline $\mathrm{Cr}$ & $200-6,822$ & 1,622 & 1,410 & 1,064 \\
\hline $\mathrm{Cu}$ & $30.8-221$ & 101 & 99.3 & 34.7 \\
\hline $\mathrm{Fe}$ & $95.0-110,418$ & 82,950 & 84,711 & 14,502 \\
\hline $\mathrm{Mn}$ & $1,007-1,835$ & 1,389 & 1,363 & 175 \\
\hline $\mathrm{Ni}$ & $102-2,295$ & 918 & 883 & 464 \\
\hline $\mathrm{Pb}$ & $18.5-46.6$ & 29.2 & 29.1 & 5.78 \\
\hline $\mathrm{Zn}$ & $63.0-242$ & 110 & 112 & 24.8 \\
\hline
\end{tabular}

Table 6. Trace element content $(\mathrm{mg} / \mathrm{kg})$ and $\mathrm{pH}$ of serpentine soil samples ( $\mathrm{N}=74$, Pingarela mine).

The Ni hyperaccumulating endemic of this region is Alyssum serpyllifolium subsp. lusitanicum, which concentrated 38,105 $\mathrm{mg} \mathrm{Ni} / \mathrm{kg}$ DW in the aboveground tissues (Figure 18). Bromus hordeaceus with 1,467 mg Ni/kg DW and Linaria spartea with $492 \mathrm{mg} \mathrm{Ni} / \mathrm{kg} \mathrm{DW}$ in the aerial parts, also showed high concentration of Ni. Four other taxa viz. - Plantago radicata, Ulmus procera, Lavandula stoechas and Cistus salvifolius showed more than $100 \mathrm{mg} \mathrm{Ni} / \mathrm{kg}$ DW (Figure 18).

Chromium has low solubility in the serpentine soil solution due to the relatively high $\mathrm{pH}$ values of these soils [83]. This is reflected in the low uptake of this element by plants, which in general did not exceed $40 \mathrm{mg} / \mathrm{kg}$. However, concentrations of $707 \mathrm{mg} \mathrm{Cr} / \mathrm{kg} \mathrm{DW}$ were reported in the above ground parts of L. spartea (Figure 19). Alyssum serpyllifolium also presented high content of $\mathrm{Cr}$, reaching a maximum of $130 \mathrm{mg} \mathrm{Cr} / \mathrm{kg}$ DW. Ulmus procera showed a content of $173 \mathrm{mg} \mathrm{Cr} / \mathrm{kg} \mathrm{DW}$ in the twigs.

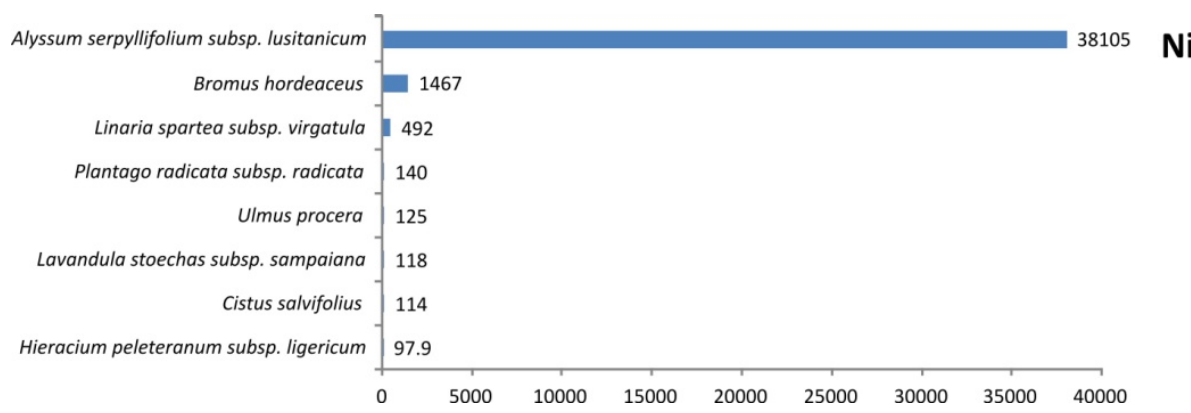

Figure 18. Accumulation of $\mathrm{Ni}(\mathrm{mg} / \mathrm{kg} \mathrm{DW})$ in serpentine plant species of the Pingarela mining area. 


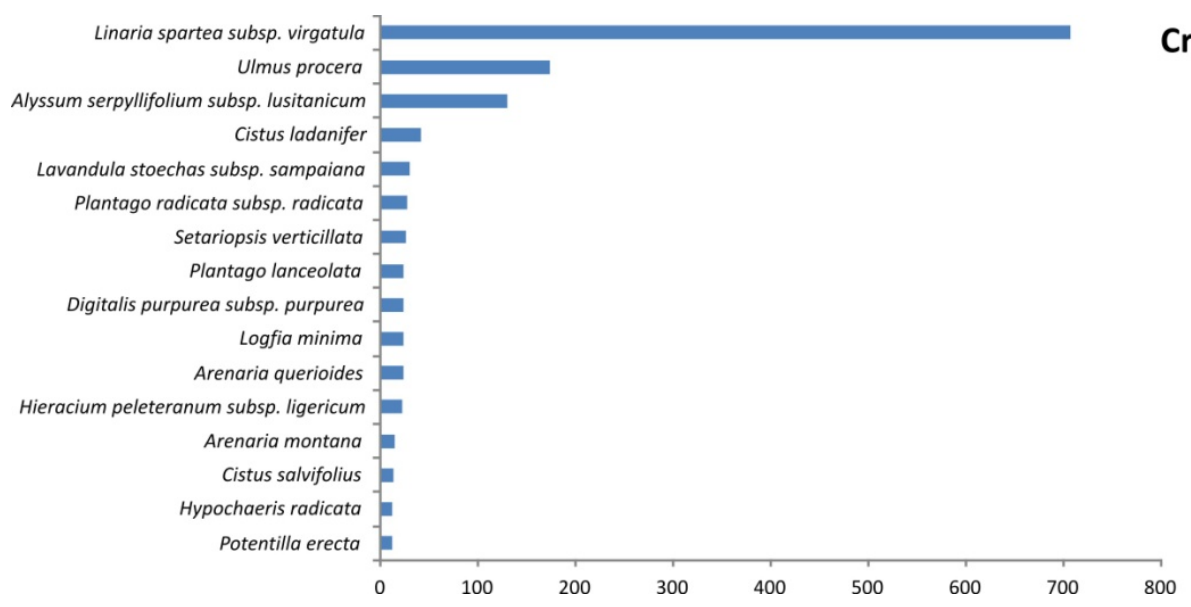

Figure 19. Accumulation of $\mathrm{Cr}(\mathrm{mg} / \mathrm{kg} \mathrm{DW})$ in serpentine plant species of the Pingarela mining area.

Although leaves of serpentine plants show 10 times higher Co levels than those of plants growing on non-serpentine soils, the absolute concentrations are only about $10 \mathrm{mg} / \mathrm{kg} \mathrm{DW}$ in most species. In this study highest accumulation of Co was found in the aboveground tissues of A. serpyllifolium with $145 \mathrm{mg} \mathrm{Co} / \mathrm{kg}$ DW and L. spartea with $63.2 \mathrm{mg} \mathrm{Co} / \mathrm{kg} \mathrm{DW} \mathrm{[83].}$

\section{Conclusion}

The physico-chemical properties of the metalliferous or metal-contaminated soils tend to inhibit soil-forming processes and plant growth. In addition to elevated metal/metalloid concentrations, other adverse factors included absence of topsoil, erosion, drought, compaction, wide temperature fluctuations, absence of soil-forming fine materials and shortage of essential nutrients $[84,101]$. Degraded soils of mines usually have low concentrations of important nutrients, like N, P and K [102]. Toxic metals can also adversely affect the number, diversity and activity of soil organisms, inhibiting soil organic matter decomposition and $\mathrm{N}$ mineralization processes. The chemical form of the potential toxic metal, the presence of other chemicals which may aggravate or attenuate metal toxicity, the prevailing $\mathrm{pH}$ and the poor nutrient status of contaminated soil affects the way in which plants respond to it. Substrate $\mathrm{pH}$ affects plant growth mainly through its effect on the solubility of chemicals, including toxic metals and nutrients.

Metal toxicity issues do not generally arise in the case of native flora, considering that native plants become adapted over time to the locally elevated metal levels [76,103]. Native plants may be better phytoremediators for contaminated lands than the known metal hyperaccumulators because these are generally slow growing with shallow root systems and low biomass. Plants tolerant to toxic metals and low nutrient status with a high rate of growth and biomass are the ideal species to remediate degraded soils and habitats like those around mines. The 
native flora displayed its ability to withstand high concentrations of heavy metals in the soil. Some species also displayed variable accumulation patterns for metals at different soil concentrations. This variation was also observed in different parts of the same plant suggesting that full consideration of plant-soil interactions should be taken into account when choosing plant species for developing and utilizing methods such as phytoremediation.

Indigenous plant species growing on tailings and contaminated soils show tolerance to imposed stress conditions (metal-contamination and nutrient deficiency) and can fulfill the objectives of stabilization, pollution attenuation and visual improvement. Besides, these species are drought-resistant and some even exhibit high biomass and bioproductivity. In fact, the constraints related to plant establishment and amendment of the physical-chemical properties of the metalliferous soils depends upon the choice of appropriate plant species. Hence, the plant community tolerant to toxic trace elements plays a major role in remediation of degraded mine soils.

The existing natural plant cover at abandoned mining sites can be increased manifold by widescale planting and maintenance of native species with higher metal accumulation potential for some years. Even dispersal of seeds obtained from plants on site is to be encouraged. Adding organic amendment is essential to facilitate the establishment and colonization of these "pioneer plants". They can eventually modify the man-made habitat and render it more suitable for subsequent plant communities. Allowing native species to remediate soils is an attractive proposition since native wild species do not require frequent irrigation, fertilization, and pesticide treatments, while simultaneously a plant community comparable to that existing in the vicinity can be established.

Therefore, mine restoration could benefit from a broader perspective including different groups of plant species as they can perform distinct functional roles in the remediation process. The use of leguminous plants, for example, may enrich the nutrient content and the combined used of perennials and annuals can provide substantial inputs in terms of organic matter and nutrient recycling, thus contributing in distinct ways to the development of the soil $[82,104]$. This approach requires more information about plant communities growing on metalcontaminated soils in order to accurately determine their potential for remediation of polluted soils at abandoned mines. Ideal phytoremedial candidates can be screened out from the native flora and after assessing their individual requirements, suitable conditions/amendments can be created to develop them as good competitors with enhanced growth and proliferation than their counterparts growing on the same metal contaminated nutrient depleted soils.

Significant accumulation of heavy metals and metalloids in both soils and native wild flora suggests that metal contamination is a matter of great concern in the studied mining areas. The native flora displayed its ability to withstand high concentrations of heavy metals/ metalloids in the soil. However, accumulation patterns of metals/metalloids in the plants tested differed. As metal concentrations in above ground parts were maintained at low levels, metal tolerance in most cases may mainly depend on their metal excluding ability. However, metal/metalloid concentrations higher than toxic level in some species like Agrostis castellana (for As, and Fe), Cistus ladanifer subsp. ladanifer (for Cr, and W), Cistus 
salvifolius (for $\mathrm{Ni}$, and $\mathrm{Pb}$ ), Digitalis purpurea subsp. purpurea (for $\mathrm{Sb}, \mathrm{W}$, and $\mathrm{Zn}$ ), Helichrysum stoechas and Hypochaeris radicata (for U), Holcus lanatus (for As, $\mathrm{Cu}$, and $\mathrm{Fe}$ ), Lonicera periclymenum, Mentha suaveolens and Phytolacca americana (for $\mathrm{Pb}$, and $\mathrm{Zn}$ ), Pinus pinaster (for As, W, and Zn), Polystichum setiferum and Solanum nigrum subsp nigrum (for Zn), Pteridium aquilinum (for As), as well as the serpentine plant species Alyssum serpyllifolium subsp. lusitanicum, Lavandula stoechas subsp. sampaiana, Linaria spartea subsp. virgatula and Ulmus procera (for $\mathrm{Cr}$, and $\mathrm{Ni}$ ) and Bromus hordeaceus and Plantago radicata subsp. radicata (for $\mathrm{Ni}$ ) indicate that internal detoxification metal tolerance mechanisms might also exist; therefore, their utility for phytoremediation is possible. Furthermore, the plants could grow and propagate in substrata with low nutrient conditions which would be a great advantage in the revegetation of mine tailings. It was also observed that despite lower accumulation, trees of the studied regions can be very effective due to their higher biomass.

Some of the studied species also showed variable accumulation patterns for metals at different soil concentrations. This difference was also noted between parts of the same plant suggesting that full consideration of plant-soil interactions should be taken into account when choosing plant species for developing and utilizing methods such as phytoremediation.

\section{Acknowledgements}

This study was partially supported by the European Fund for Economic and Regional Development (FEDER) through the Program Operational Factors of Competitiveness (COMPETE) and National Funds through the Portuguese Foundation for Science and Technology (PEST-C/MAR/UI 0284/2011, FCOMP 010124 FEDER 022689).

\section{Author details}

Paulo J.C. Favas ${ }^{1,3^{*}}$, João Pratas ${ }^{2,3}$, Mayank Varun $^{4}$, Rohan D'Souza ${ }^{4}$ and Manoj S. Paul ${ }^{4}$

*Address all correspondence to: pjcf@utad.pt

1 University of Trás-os-Montes e Alto Douro, UTAD, School of Life Sciences and the Environment, Vila Real, Portugal

2 Department of Earth Sciences, Faculty of Sciences and Technology, University of Coimbra, Coimbra, Portugal

3 IMAR-CMA Marine and Environmental Research Centre, Faculty of Sciences and Technology, University of Coimbra, , Portugal

4 Department of Botany, St. John's College, Agra, India 


\section{References}

[1] Evanko CR, Dzombak DA. Remediation of metals-contaminated soils and groundwater. Technology Evaluation Report. Pittsburgh: GWRTAC - Ground-Water Remediation Technologies Analysis Center; 1997.

[2] Gómez Orea D. Recuperación de espacios degradados. Madrid, Barcelona, México: Ediciones Mundi-Prensa; 2004.

[3] Prasad MNV. Phytoremediation of metals and radionuclides in the environment: the case for natural hyperaccumulators, metal transporters, soil-amending chelators and transgenic plants. In: Prasad MNV. (ed.) Heavy metal stress in plants: from biomolecules to ecosystems, Second Edition. Berlin: Springer; 2004. p345-391.

[4] Chaney RL, Malik M, Li YM, Brown SL, Angle JS, Baker AJM. Phytoremediation of soil metals. Current Opinion in Biotechnology 1997; 8 279-284.

[5] Ensley BD. Rationale for use of phytoremediation. In: Raskin I, Ensley BD. (ed.) Phytoremediation of toxic metals. Using plants to clean up the environment. New York: John Wiley \& Sons, Inc.; 2000. p3-11.

[6] Prasad MNV, Freitas HMO. Metal hyperaccumulation in plants - Biodiversity prospecting for phytoremediation technology. Electronic Journal of Biotechnology 2003; 6(3) 285-321.

[7] Mendez MO, Maier RM. Phytoremediation of mine tailings in temperate and arid environments. Reviews in Environmental Science and Biotechnology 2008; 7 47-59.

[8] Dickinson NM, Baker AJM, Doronila A, Laidlaw S, Reeves RD. Phytoremediation of inorganics: realism and synergies. International Journal of Phytoremediation 2009; 11 97-114.

[9] Schnoor JL, Licht LA, McCutcheon SC, Wolfe NL, Carreira LH. Phytoremediation of organic and nutrient contaminants. Environmental Science \& Technology 1995; 29 318A-323A.

[10] Rylott EL, Bruce NC. Plants disarm soil: engineering plants for the phytoremediation of explosives. Trends in Biotechnology 2008; 27(2) 73-81.

[11] Berti WR, Cunningham SD. Phytostabilization of metals. In: Raskin I, Ensley BD. (ed.) Phytoremediation of toxic metals. Using plants to clean up the environment. New York: John Wiley \& Sons, Inc.; 2000. p71-88.

[12] Domínguez MT, Madrid F, Marañón T, Murillo JM. Cadmium availability in soil and retention in oak roots: potential for phytostabilization. Chemosphere 2009; 76 480-486.

[13] Ali H, Khan E, Sajad MA. Phytoremediation of heavy metals - Concepts and applications. Chemosphere 2013; 91 869-881. 
[14] Brooks RR. Phytoremediation by volatilisation. In: Brooks RR. (ed.) Plants that hyperaccumulate heavy metals: their role in phytoremediation, microbiology, archaeology, mineral exploration and phytomining. New York: CAB International; 1998. p289-312.

[15] Pilon-Smits E, Pilon M. Breeding mercury-breathing plants for environmental cleanup. Trends in Plant Science 2000; 5(6) 235-236.

[16] Poschenrieder CH, Barceló J. Estrés por metales pesados. In: Reigosa MJ, Pedrol N, Sánchez A. (eds.) La ecofisiologia vegetal: Una ciencia de síntesis. Madrid: Thomson; 2004. p413-442.

[17] Ruiz ON, Daniell H. Genetic engineering to enhance mercury phytoremediation. Current Opinion in Biotechnology 2009; 20 213-219.

[18] Pilon-Smits EAH, LeDuc DL. Phytoremediation of selenium using transgenic plants. Current Opinion in Biotechnology 2009; 20 207-212.

[19] McGrath SP. Phytoextraction for soil remediation. In: Brooks RR. (ed.) Plants that hyperaccumulate heavy metals: their role in phytoremediation, microbiology, archaeology, mineral exploration and phytomining. New York: CAB International; 1998. p261-287.

[20] Blaylock MJ, Huang JW. Phytoextraction of metals. In: Raskin I, Ensley BD. (ed.) Phytoremediation of toxic metals. Using plants to clean up the environment. New York: John Wiley \& Sons, Inc.; 2000. p53-70.

[21] Ma LQ, Komar KM, Tu C, Zhang W, Cai Y, Kennelley ED. A fern that hyperaccumulates arsenic. Nature 2001; 409579.

[22] McGrath SP, Zhao FJ. Phytoextraction of metals and metalloids from contaminated soils. Current Opinion in Biotechnology 2003; 14 277-282.

[23] Hernández-Allica J, Becerril JM, Garbisu C. Assessment of the phytoextraction potential of high biomass crop plants. Environmental Pollution 2008; 152 32-40.

[24] Pedron F, Petruzzelli G, Barbafieri M, Tassi E. Strategies to use phytoextraction in very acidic soil contaminated by heavy metals. Chemosphere 2009; 75 808-814.

[25] Xie QE, Yan XL, Liao XY, Li X. The arsenic hyperaccumulator fern Pteris vittata L. Environmental Science \& Technology 2009; 43(22) 8488-8495.

[26] Van der Ent A, Baker AJM, Reeves RD, Pollard AJ, Schat H. Hyperaccumulators of metal and metalloid trace elements: Facts and fiction. Plant Soil 2013; 362 319-334.

[27] Frers C. El uso de plantas acuáticas en el tratamiento de aguas residuales. Carmen de Areco, Argentina: El Planeta Azul; 2009.

[28] Dhote S, Dixit S. Water quality improvement through macrophytes - a review. Environmental Monitoring and Assessment 2009; 152 149-153. 
[29] Dushenkov S, Kapulnik Y. Phytofiltration of metals. In: Raskin I, Ensley BD. (ed.) Phytoremediation of toxic metals. Using plants to clean up the environment. New York: John Wiley \& Sons, Inc.; 2000. p89-106.

[30] Pratas J, Favas PJC, Paulo C, Rodrigues N, Prasad MNV. Uranium accumulation by aquatic plants from uranium-contaminated water in Central Portugal. International Journal of Phytoremediation 2012; 14 221-234.

[31] Favas PJC, Pratas J, Prasad MNV. Accumulation of arsenic by aquatic plants in largescale field conditions: Opportunities for phytoremediation and bioindication. Science of the Total Environment 2012; 433 390-397.

[32] Crowley DE, Alvey S, Gilbert ES. Rhizosphere ecology of xenobiotic-degrading microorganisms. In: Kruger EL, Anderson TA, Coats JR. (eds.) Phytoremediation of Soil and Water Contaminants. Washington: ACS Symposium Series; 1997. p20-36.

[33] Khan MS, Zaidi A, Wani PA, Oves M. Role of plant growth promoting rhizobacteria in the remediation of metal contaminated soils. Environmental Chemistry Letters 2009; 7 1-19.

[34] Schnoor JL. Phytostabilization of metals using hybrid poplar trees. In: Raskin I, Ensley BD. (ed.) Phytoremediation of toxic metals. Using plants to clean up the environment. New York: John Wiley \& Sons, Inc.; 2000. p133-150.

[35] Williamson NA, Johnson MS, Bradshaw AD. Mine Wastes Reclamation. The Establishment of Vegetation on Metal Mine Wastes. London: Mining Journal Books; 1982.

[36] Brooks RR, Chiarucci A, Jaffré T. Revegetation and stabilization of mine dumps and other degraded terrain. In: Brooks RR. (ed.) Plants that hyperaccumulate heavy metals: their role in phytoremediation, microbiology, archaeology, mineral exploration and phytomining. New York: CAB International; 1998. p227-247.

[37] Jorba M, Vallejo R. La restauración ecológica de canteras: un caso con aplicación de enmiendas orgánicas y riegos. Ecosistemas 2008; 17(3) 119-132.

[38] González V. A indústria extractiva e o ambiente. Boletim de Minas 1990; 27(3) 311-323.

[39] Vymazal J. The use constructed wetlands with horizontal sub-surface flow for various types of wastewater. Ecological Engineering 2009; 35 1-17.

[40] Fonder N, Headley T. The taxonomy of treatment wetlands: A proposed classification and nomenclature system. Ecological Engineering 2013; 51 203-211.

[41] Horne AJ. Phytoremediation by constructed wetlands. In: Terry N, Bañuelos G. (eds.) Phytoremediation of contaminated soil and water. New York: Lewis Publishers; 2000. p13-39. 
[42] Sobolewski A. A review of processes responsible for metal removal in wetlands treating contaminated mine drainage. International Journal of Phytoremediation 1999; 1(1) 19-51.

[43] López Pamo E, Aduvire O, Barettino D. Tratamientos pasivos de drenajes ácidos de mina: estado actual y perspectivas de futuro. Boletín Geológico y Minero 2002; 113(1) 3-21.

[44] Nyquist J, Greger M. A field study of constructed wetlands for preventing and treating acid mine drainage. Ecological Engineering 2009; 35 630-642.

[45] Adams A, Raman A, Hodgkins D. How do the plants used in phytoremediation in constructed wetlands, a sustainable remediation strategy, perform in heavy-metalcontaminated mine sites? Water and Environment Journal 2013; 27(3) 373-386.

[46] Zorrig W, Rabhi M, Ferchichi S, Smaoui A, Abdelly C. Phytodesalination: a solution for salt-affected soils in arid and semi-arid regions. Journal of Arid Land Studies 2012; 22 299-302.

[47] Ravindran KC, Venkatesan K, Balakrishnan V, Chellappan KP, Balasubramanian T. Restoration of saline land by halophytes for Indian soils. Soil Biology \& Biochemistry 2007; 39 2661-2664.

[48] Glass DJ. Economic potential of phytoremediation. In: Raskin I, Ensley BD. (ed.) Phytoremediation of toxic metals. Using plants to clean up the environment. New York: John Wiley \& Sons, Inc.; 2000. p15-31.

[49] Van Nevel L, Mertens J, Oorts K, Verheyen K. Phytoextraction of metals from soils: How far from practice? Environmental Pollution 2007; 150 34-40.

[50] Nascimento CWA, Xing B. Phytoextraction: a review on enhanced metal availability and plant accumulation. Scientia Agricola 2006; 63(3) 299-311.

[51] Zhuang P, Yang QW, Wang HB, Shu WS. Phytoextraction of heavy metals by eight plant species in the field. Water, Air, and Soil Pollution 2007; 184 235-242.

[52] Sakakibara M, Ohmori Y, Ha NTH, Sano S, Sera K. Phytoremediation of heavy metal contaminated water and sediment by Eleocharis acicularis. Clean: Soil, Air, Water 2011; 39 735-741.

[53] Shabani N, Sayadi MH. Evaluation of heavy metals accumulation by two emergent macrophytes from the polluted soil: an experimental study. Environmentalist 2012; 32 91-98.

[54] Pierzynski G, Kulakow P, Erickson L, Jackson L. Plant system technologies for environmental management of metals in soils: Educational materials. Journal of Natural Resources and Life Science Education 2002; 31 31-37.

[55] Saifullah, Meers E, Qadir M, Caritat P, Tack FMG, Laing GD, Zia MH. EDTA-assisted $\mathrm{Pb}$ phytoextraction. Chemosphere 2009; 74(10) 1279-1291. 
[56] Tu S, Ma LQ. Comparison of arsenic and phosphate uptake and distribution in arsenic hyperaccumulating and nonhyperaccumulating fern. Journal of Plant Nutrition $2004 ; 27(7)$ 1227-1242.

[57] Liang HM, Lin TH, Chiou JM, Yeh KC. Model evaluation of the phytoextraction potential of heavy metal hyperaccumulators and non-hyperaccumulators. Environmental Pollution 2009; 157 1945-1952.

[58] Antosiewicz DM, Escudĕ-Duran C, Wierzbowska E, Skłodowska A. Indigenous plant species with the potential for the phytoremediation of arsenic and metals contaminated soil. Water, Air, \& Soil Pollution 2008; 193 197-210.

[59] Doyle MO, Otte ML. Organism-induced accumulation of iron, zinc and arsenic in wetland soil. Environmental Pollution 1997; 96 1-11.

[60] Mains D, Craw D, Rufaut C, Smith C. Phytostabilization of gold mine tailings from New Zealand. Part 2: Experimental evaluation of arsenic mobilization during revegetation. International Journal of Phytoremediation 2006; 8 163-183.

[61] Baker AJM. Accumulators and excluders - strategies in the response of plants to heavy metals. Journal of Plant Nutrition 1981; 3 643-654.

[62] Baker AJM, Walker PL. Ecophysiology of metal uptake by tolerant plants. In: Shaw AJ. (ed.) Heavy metal tolerance in plants: Evolutionary aspects. Boca Raton, Florida: CRC Press, Inc.; 1990. p155-193.

[63] Becerril JM, Barrutia JL, Garcia Plazaola A, Hernández A, Olano JM, Garbisu C. Especies nativas de suelos contaminados por metales: aspectos ecofisiológicos y su uso en fitorremediación. Ecosistemas 2007; 16(2) 50-55.

[64] Becerra-Castro C, Monterroso C, Prieto-Fernández A, Rodríguez-Lamas L, LoureiroViñas M, Acea MJ, Kidd PS. Pseudometallophytes colonising Pb/Zn mine tailings: A description of the plant-microorganism-rhizosphere soil system and isolation of metal-tolerant bacteria. Journal of Hazardous Materials 2012; 217/218 350-359.

[65] Quintela-Sabarís C, Ribeiro MM, Poncet B, Costa R, Castro-Fernández D, Fraga MI. AFLP analysis of the pseudometallophyte Cistus ladanifer: comparison with cpSSRs and exploratory genome scan to investigate loci associated to soil variables. Plant and Soil 2012; 359 397-413.

[66] Ernst W. Mine vegetation in Europe. In: Shaw AJ. (ed.) Heavy Metal Tolerance in Plants: Evolutionary Aspects. Boca Raton, Florida: CRC Press, Inc.; 1990. p21-37.

[67] Robinson BH, Chiarucci A, Brooks RR, Petit D, Kirkman JH, Gregg PEH, DeDominicis V. The nickel hyperaccumulator plant Alyssum bertolonii as a potential agent for phytoremediation and phytomining of nickel. Journal of Geochemical Exploration 1997; 59 75-86. 
[68] Poschenrieder C, Bech J, Llugany M, Pace A, Fenes E, Barceló J. Copper in plant species in a copper gradient in Catalonia (North East Spain) and their potential for phytoremediation. Plant and Soil 2001; 230(2) 247-256.

[69] Madejón P, Murillo JM, Marañon T, Cabrera F, López R. Bioaccumulation of As, Cd, $\mathrm{Cu}, \mathrm{Fe}$ and $\mathrm{Pb}$ in wild grasses affected by the Aznalcóllar mine spill (SW Spain). Science of the Total Environment 2002; 290 105-120.

[70] Kidd PS, Monterroso C. Metal extraction by Alyssum serpyllifolium ssp. lusitanicum on mine-spoil soils from Spain. Science of the Total Environment 2005; 336 1-11.

[71] Yanqun Z, Yuan L, Jianjun C, Haiyan C, Li Q, Schvartz C. Hyperaccumulation of Pb, $\mathrm{Zn}$ and $\mathrm{Cd}$ in herbaceous grown on lead-zinc mining area in Yunnan, China. Environment International 2005; 31 755-762.

[72] Rodríguez N, Amils R, Jiménez-Ballesta R, Rufo L, De la Fuente V. Heavy metal content in Erica andevalensis: an endemic plant from the extreme acidic environment of Tinto River and its soils. Arid Land Research and Management 2007; 21 51-65.

[73] Saraswat S, Rai JPN. Phytoextraction potential of six plant species grown in multimetal contaminated soil. Chemistry and Ecology 2009; 25(1) 1-11.

[74] D'Souza R, Varun M, Masih J, Paul MS. Identification of Calotropis procera L. as a potential phytoaccumulator of heavy metals from contaminated soils in Urban North Central India. Journal of Hazardous Materials 2010; 184 457-464.

[75] Lorestani B, Cheraghi M, Yousefi N. Phytoremediation potential of native plants growing on a heavy metals contaminated soil of copper mine in Iran. World Academy of Science, Engineering and Technology 2011; 53 377-382.

[76] Varun M, D'Souza R, Pratas J, Paul MS.. Metal contamination of soils and plants associated with the glass industry in North-central India: prospects of phytoremediation. Environmental Science and Pollution Research 2012; 19 269-281.

[77] Maric M, Antonijevic M, Alagic S. The investigation of the possibility for using some wild and cultivated plants as hyperaccumulators of heavy metals from contaminated soil. Environmental Science and Pollution Research 2013; 20 1181-1188.

[78] Zhang Z, Sugawara K, Hatayama M, Huang Y, Inoue C. Screening of As-accumulating plants using a foliar application and a native accumulation of As. International Journal of Phytoremediation 2013; doi:10.1080/15226514.2013.773277.

[79] De Koe T, Beek M, Haarsma M, Ernst W. Heavy metals and arsenic grasses and soils of mine spoils in North East Portugal, with particular reference to some Portuguese goldmines. In: Nath B. (ed.) Environmental Pollution 1. Proc. Int. Conf. ICEP-1; 1991. p373-380. 
[80] Henriques FS, Fernandes JC. Metal uptake and distribution in rush (Juncus conglomeratus L.) plants growing in pyrite mine tailings at Lousal, Portugal. Science of the Total Environment 1991; 102 253-260.

[81] Alvarenga PM, Araújo MF, Silva JAL. Elemental uptake and root-leaves transfer in Cistus ladanifer L. growing in a contaminated pyrite mining area (Aljustrel - Portugal). Water, Air, and Soil Pollution 2004; 162 81-96.

[82] Freitas H, Prasad MNV, Pratas J. Plant community tolerant to trace elements growing on the degraded soils of São Domingos mine in the south east of Portugal: environmental implications. Environment International 2004; 30 65-72.

[83] Freitas H, Prasad MNV, Pratas J. Analysis of serpentinophytes from north-east of Portugal for trace metal accumulation - relevance to the management of mine environment. Chemosphere 2004; 54 1625-1642.

[84] Pratas J, Prasad MNV, Freitas H, Conde L. Plants growing in abandoned mines of Portugal are useful for biogeochemical exploration of arsenic, antimony, tungsten and mine reclamation. Journal of Geochemical Exploration, 2005; 85 99-107.

[85] Díez Lázaro J, Kidd PS, Monterroso Martínez C. A phytogeochemical study of the Trás-os-Montes region (NE Portugal): Possible species for plant-based soil remediation technologies. Science of the Total Environment 2006; 354 265-277.

[86] Branquinho C, Serrano HC, Pinto MJ, Martins-Loução MA. Revisiting the plant hyperaccumulation criteria to rare plants and earth abundant elements. Environmental Pollution 2007; 146 437-443.

[87] Turnau K, Henriques FS, Anielska T, Renker C, Buscot F. Metal uptake and detoxification mechanisms in Erica andevalensis growing in a pyrite mine tailing. Environmental and Experimental Botany 2007; 61 117-123.

[88] Abreu MM, Tavares MT, Batista MJ. Potential use of Erica andevalensis and Erica australis in phytoremediation of sulphide mine environments: São Domingos, Portugal. Journal of Geochemical Exploration 2008; 96 210-222.

[89] Marques APGC, Moreira H, Rangel AOSS, Castro PML. Arsenic, lead and nickel accumulation in Rubus ulmifolius growing in contaminated soil in Portugal. Journal of Hazardous Materials 2009; 165 174-179.

[90] Anawar HM, Freitas MC, Canha N, Santa Regina I. Arsenic, antimony, and other trace element contamination in a mine tailings affected area and uptake by tolerant plant species. Environmental Geochemistry and Health 2011; 33(4) 353-362.

[91] Abreu MM, Santos ES, Ferreira M, Magalhães MCF. Cistus salviifolius a promising species for mine wastes remediation. Journal of Geochemical Exploration 2012; 113 86-93. 
[92] Pratas J, Favas PJC, D'Souza R, Varun M, Paul MS. Phytoremedial assessment of flora tolerant to heavy metals in the contaminated soils of an abandoned $\mathrm{Pb}$ mine in Central Portugal. Chemosphere 2013; 90 2216-2225.

[93] Favas PJC, Pratas J, Prasad MNV. Temporal variation in the arsenic and metal accumulation in the maritime pine tree grown on contaminated soils. International Journal of Environmental Science and Technology 2013; 10(4) 809-826.

[94] Favas PJC, Pratas JAMS, Conde LEN. Bioaccumulation of heavy metals in plants that colonize tailings (Vale das Gatas mine - Vila Real - North of Portugal). In: Prego R, Duarte A, Panteleitchouk A, Santos TR. (eds.) Studies on Environmental Contamination in Iberian Peninsula. Lisbon: Instituto Piaget; 2002. p259-272. (in Portuguese)

[95] Gaspar OC. História da mineração dos depósitos de sulfuretos maciços vulcanogénicos da Faixa Piritosa Portuguesa. Boletim de Minas 1998; 35(4) 401-414.

[96] Kabata-Pendias A. Trace Elements in Soils and Plants, 4th ed. Boca Raton: CRC Press; 2010.

[97] Canadian Council of Ministers for the Environment. Canadian soil quality guidelines for the protection of environmental and human health, update 6.02, Publication no. 1299, ISBN 1-896997-34-1. 2006.

[98] Alloway BJ. Heavy Metals in Soils. London: Blackie Academic \& Professional; 1990.

[99] Favas P, Pratas J. Uranium in soils, waters and plants of the an abandoned uranium mine (Central Portugal). In: $12^{\text {th }}$ International Multidisciplinary Scientific GeoConference (SGEM 2012) Conference Proceedings Vol. V, 17-23 June 2012, Albena, Bulgaria. Albena: STEF92 Technology Ltd.; 2012. p1023-1028.

[100] Reeves RD, Baker AJM, Borhidi A, Berazain R. Nickel-accumulating plants from the ancient serpentine soils of Cuba. New Phytologist 1996; 133 217-224.

[101] Wong MH. Ecological restoration of mine degraded soils with emphasis on metal contaminated soils. Chemosphere 2003; 50 775-780.

[102] Huenneke LF, Hamburg SP, Koide R, Mooney HA, Vitousek PM. Effects of soil resources on plant invasion and community structure in Californian serpentine grassland. Ecology 1990; 71(2) 478-491.

[103] D'Souza R, Varun M, Pratas J, Paul MS. Spatial distribution of heavy metals in soil and flora associated with the glass industry in North Central India: implications for phytoremediation. Soil and Sediment Contamination 2013; 22 1-20.

[104] Hooper DU, Vitousek PM. The effects of plant composition and diversity on ecosystem processes. Science 1997; 277 1302-1305. 
